\title{
THE AMERICAN PRESIDENCY
}

\section{Richard M. Pious}

"A major contribution... will doubtless be one of the few lasting books about the presidency."-Thomas E. Cronin. The first comprehensive assessment of the American presidency in more than a decade, this major new work demonstrates that what a president is able to accomplish usually has less to do with politics than with his willingness to assert his constitutional authority to resolve important national issues. In developing his thesis, the author places great emphasis on the weakness of the presidency as an economic arranger. Pious is Assistant Professor of Political Science at Barnard College.

Due January 1979/cloth, \$15.00/paper, $\$ 6.95$

\section{CAN GOVERNMENTS GO BANKRUPT? Richard Rose \& Guy Peters}

The first attempt to deal with the political consequences of the modern welfare stateNew York City writ large. Drawing upon official reports and interviews, as well as an intimate acquaintance with the way governments actually work, the authors examine the pressures which are confronting politicians-in the United States, Sweden, and Britain - with an unpleasant choice: cut public spending or undermine their own authority and face political bankruptcy. Rose is Professor of Politics and Director of the Center for the Study of Public Policy at the University of Strathclyde, Glasgow. Peters is Director of the Center for Policy Studies at Tulane University.

October $1978 / \$ 12.50$

\section{Now in paperback}

\section{THE REPUBLIC OF PLATO}

Translated with Notes and an Interpretive Essay

\section{by Allan Bloom}

"The best available English translation of the Republic."-Harry Neumann, American Political Science Review.

Paper, $\$ 5.75$

\section{ANARCHY, STATE, AND UTOPIA Robert Nozick}

"A brilliant and important book, bound to contribute notably to theory and in time, to the good of society."-W.V. Quine, Harvard. Winner of the 1975 National Book Award.

Paper, \$6.95

\section{THE STATE IN CAPITALIST SOCIETY}

\section{Ralph Miliband}

“... a fascinating and compelling analysis ... of the way in which all society is manipulated to accept both the ends and means of private industry as the proper, indeed the only, ends and means of society."

-The New Statesman

Paper, $\$ 4.95$

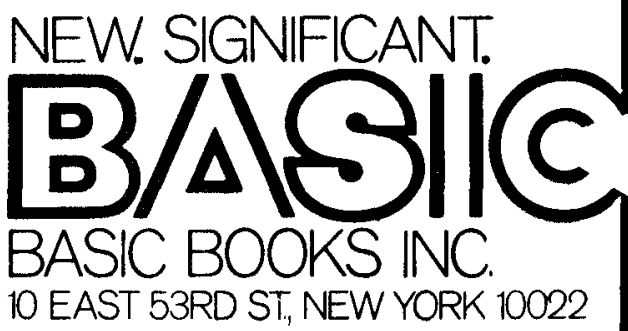



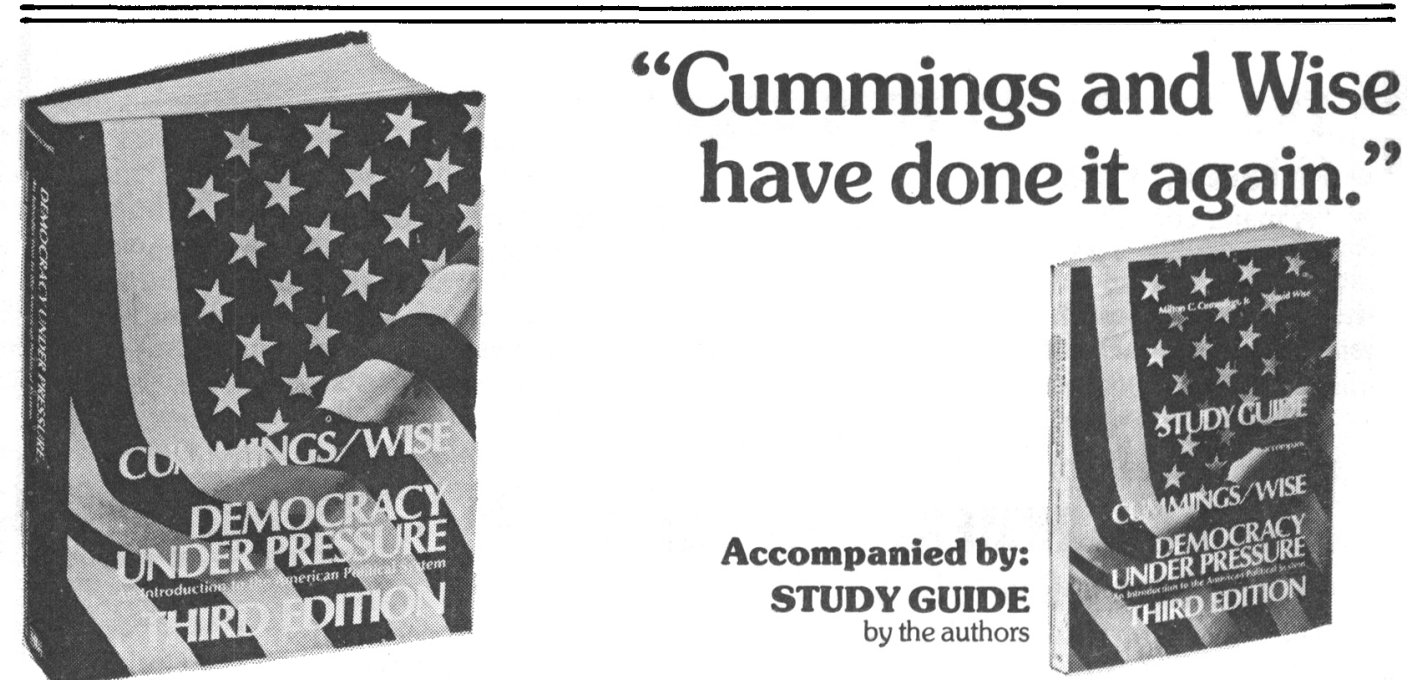

716 pages

\section{Democracy Under Pressure}

\section{An Introduction to the American Political System \\ THIRD EDITION \\ MILTON C. CUMMINGS, JR.,}

The Johns Hopkins University

\section{DAVID WISE,}

author and political analyst

The bestselling textbook for the first course in American government has been adopted at more than 430 colleges and universities since Spring 1977 publication. Here's why:

"Once again Cummings and Wise have provided us with the most stimulating and contemporaneous American government text on the market today. Students comment that it is one of the few texts that makes reading a pleasure rather than a chore. The succinct and provocative commentary provides unique insight into the strengths and weaknesses of our political system."

-WILLIAM H. JERVEY, Jr., Florida Technological University

"Cummings and Wise have done it again. Democracy Under Pressure meets the need for readable, comprehensive, and candid coverage of American politics."

$$
\text { - JERRY SULLIVAN, Lambuth College }
$$

"Highly readable, up-to-date, excellent choice of charts, tables, quotes, pictures, and graphic materials generally. I am looking forward to using it in the fall."

- JACOB A. HURWIT2, North Carolina State University

"Not in recent memory have students so enthusiastically accepted the notion that Government is a course that is worthy of their most sustained and engrossing interest. Much of the credit for this is due to this text."

-ARTHUR C. HILL, Metropolitan Community College
This Study Guide - a truly innovative and interesting entry in the field - was designed by the authors to enforce and expand upon students' comprehension of the text material. For each of the sixteen chapters in the text, the Study Guide provides:

key points - that highlight important terms and concepts and provide an overview of the chapter

glossary terms - with spaces under each item for students to attempt their own definitions; page numbers on which the correct definition appears are keyed to the text and the definition itself is given on an adjacent page in the Guide

a self quin - true-false, multiple-choice, and short answer questions

a learning unit - that tests one particular topic in the chapter through a fill-in-the-blank narrative

learning objectives

two types of study exercises - that ask the student to interpret information from charts, graphs, and tables in the text or to analyze and resolve a problem (a hypothetical court case or political dilemma, for example)

\section{TEST BOOKLET} with Lecture and Discussion Topics and Learning Objectives

ROBERT P. LAMM

Also available now for Fall classes: POWER AND BALANCE An Introduction to American Constitutional Government IRA H. CARMEN,

University of Illinois,

Champaign-Urbana

Paperbound. 582 pages Test Booklet 


\section{THE FOUNDING MEMBERS OF THE

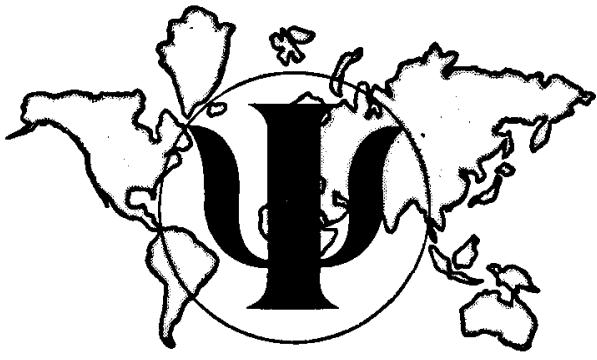 \\ INTERNATIONAL SOCIETY OF POLITICAL PSYCHOLOGY}

\section{INCLUDING}

Joseph Adelson

Gabriel Almond

Conrad Arensberg

James David Barber

Christian Bay

Fawn Brodie

Richard Brody

James MacGregor Burns

Angus Campbell

Donald T. Campbell

Philip Converse

James C. Davies

Erik H. Erikson

Ada W. Finifter

Jerome Frank

Saul Friedlander

Erich Fromm

Clifford Geertz

Alexander L. George

Betty Glad

Harold Guetzkow

Margaret G. Hermann Hilde T. Himmelweit

Francis L. K. Hsu

David Easton

Ronald Inglehant
M. Kent Jennings
Abraham Kaplan
Herbert C. Kelman
Kenneth Keniston
Jeanne N. Knutson
Lawrence Kohlberg
Robert E. Lane
Kenneth Langton
Harold D. Lasswell
Daniel Lerner
Robert Le Vine
Robert J. Lifton

Seymour M. Lipset Judd Marmor Herbert McClosky Margaret Mead

Richard M. Merelman

Warren Miller

Serge Moscovici

. Newcomb M. Brewster Smith

Talcott Parsons

Ithiel De Sola Pool Kenneth Prewitt

Stanley Renshon

Elliot L. Richardson
David Riesman

Paul Roazen Arnold Rogow Milton Rokeach

Nevitt Sanford

David $O$. Sears

Albert Somit

J. L. Talmon

Richard C. Tucker

Sydney Verba

Robert W. White

Philip Zimbardo

invite you to join with them in improving communication among those sharing this scholarly interest from different disciplinary, geographic and political viewpoints; in increasing the quality and breadth of work done by shared information about research needs, shared data and a shared forum in which to evaluate our social and ethical responsibilities ......

With membership, you receive: - a subscription to our official quarterly journal, Political Psychology, edited by Jeanne N. Knutson and David O. Sears; - the priviledge of submitting materials for publication to our journal; - the opportunity of confronting the assumptive frameworks of widely varying colleagues; - a chance to participate in the program of our annual scientific meeting (with the first meeting to be held on September 2 - 4, under the Chairmanship of Harold D. Lasswell, at the Americana Hotel in New York City); - an opportunity to hear the sessions and share in the discussion at this meeting at a dramatically reduced registration fee, and to receive the Proceedings. - all for an annual dues of only $\$ 35.00$.

NAME

INSTITUTION

ADDRESS

SPECIAL FIELDS OF INTEREST IN POLITICAL PSYCHOLOGY

WILLINGNESS TO REVIEW 3 PAPERS A YEAR FOR THE JOURNAL? REVIEW ONE BOOK A YEAR?

Return this form with your $\$ 35.00$ in dues to:

International Society of Political Psychology 


\section{MICRONESIA UNDER AMERICAN RULE by Harold F. Nufer, Ph.D. An Evaluation of the Strategic Trusteeship (1947-77)}

On July 18, 1947, President Truman signed an agreement between the United States and the U.N. Security Council mandating American trusteeship over Micronesia. Four main goals were stipulated: political development, economic progress, social improvement, educational advancement. How has the U.S. measured up in the ensuing 30 years of trusteeship?

Dr. Harold Nufer, in one of the most important studies of its kind, rates Ameri can rule on the whole as mediocre-or as he puts it, "C+." His conclusions are drawn from eleven years of investigative experience which included extensive interviews of American, Micronesian and Japanese spokesmen representing a cross section of informed opinion. A recipient of the "Outstanding Educators of America Award" for 1972, Prof. Nufer presents his findings in clear, authoritative form, leaving the concerned reader with much to ponder.
"Micronesia Under American Rule should be required reading for everyone in government service even remotely involved in geopolitical affairs . . . a sobering reve. lation in the assessment of our government's ability to manage socio-economic affairs elsewhere in the world."

$$
\begin{aligned}
& \text { Fred } M . \text { Zeder, } I I \\
& \text { Director of } \\
& \text { Territorial Affairs, } 1975.77
\end{aligned}
$$

"I would like to rate him an $\boldsymbol{\Lambda}+$ for his thorough documentation and his extremely readable presentation of a fascinating, but often confusing, erat of Micronesian history."

\section{Emilie G. Johnston \\ Curator \\ Micronesian Area \\ Research Center (MARC), Guam $\$ 15.00$}

\section{EXPOSITION PRESS, INC., DEPT. APS}

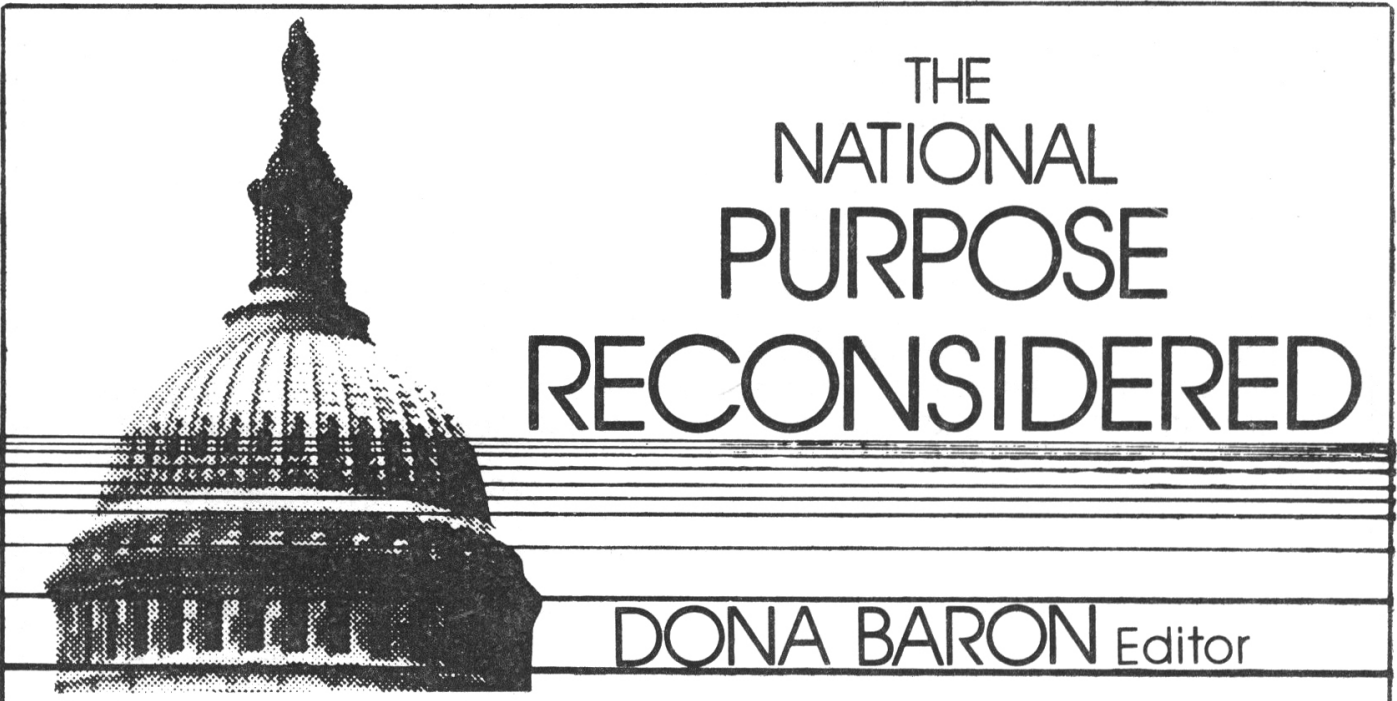

A searching examination of the forces that will shape America s future by five distinguished authorities on America's present: George W. Ball, America's Changing World Posture; Martin E. Marty, The Changing Role of Religion in American Society; Barry Commoner, Era of Constraints; Gumnar Myrdal, Race and Class in a Welfare State; John Doar, Civil Rights and Self-Government. With a prologue by the noted historian Richard B. Morris and a concluding summation by Dona Baron.

To order send check or money order to Dept. LGB. Individuals must enclose payment. Institutions may request billing 


\section{America's leading political scientists analyze governmental policy making}

\section{The Mlaking of Amerioan Foreign and Domestic Polioy}

edited by Demetrios Caraley, Professor of Political Science in Barnard College and Columbia University, and Mary Ann Epstein, Assistant Managing Editor of the Political Science Quarterly

\section{Partial Contents}

Alpheus Thomas Mason, America's Political Heritage

Robert A. Dahl, On Removing Certain Impediments to Democracy in the United States

James David Barber, The Nixon Brush with Tyranny

Doris Kearns, Lyndon Johnson's Political Personality

Richard E. Neustadt, Staffing the Presidency

Nelson W. Polsby, Presidential Cabinet Making

Demetrios Caraley, Congressional Politics and Urban Aid

Hugh Heclo, Political Executives and the Washington Bureaucracy

Robert J. Steamer, Contemporary Supreme Court Directions in Civil Liberties

Bruce Russett, The Americans' Retreat from World Power

Walter LaFeber, Kissinger and Acheson

Robert J. Bresler \& Robert C. Gray, The Bargaining Chip and SALT

Aaron Wildavsky et. al., Oil and the Decline of Western Power

William J. Foltz, United States Policy toward Southern Africa

Alan A. Platt \& Robert Leonardi, American Foreign Policy and the Postwar Italian Left

Sar A. Levitan \& Robert Taggart, The Great Society Did Succeed

Everett Carll Ladd, Jr., Liberalism Upside Down

Richard P. Nathan et. al., Monitoring the Block Grant Program

for Community Development

Congressional Budget Office, The Causes of New York City's Fiscal Crisis

Michael N. Danielson, The Politics of Exclusionary Zoning in Suburbia

Just Published

INDEX

ISBN: 0-89561-070-1

512 pages

Essays from the Political Science Quarterly

$\$ 9.95$ paper/\$17.95 cloth

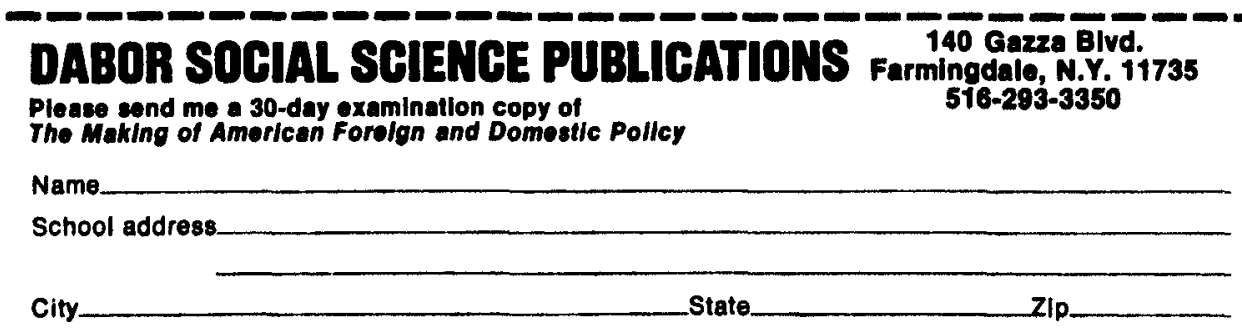




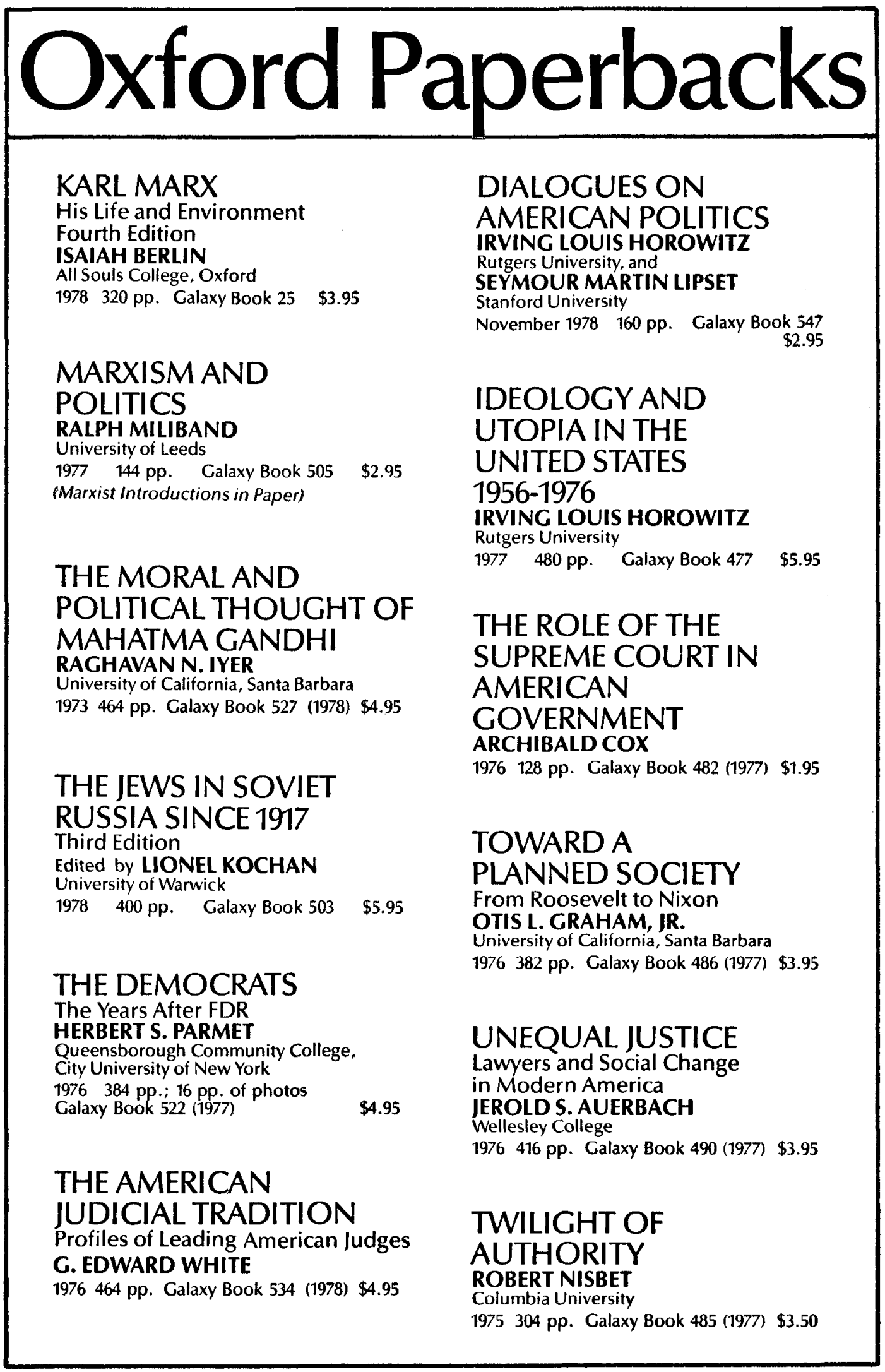


KARL MARX:

\section{Selected Writings}

Edited by DAVID McLELLAN, University of Kent. "It is thoughtfully selected, the translations are both readable and highly accurate, and the coverage is generous yet discriminating. It is a first-rate collection, probably the best of its kind." -Sheldon S. Wolin, Princeton University

$1977 \quad 640$ pp. cloth $\$ 12.00$ paper $\$ 6.00$

\section{AUSTRO-MARXISM}

Texts edited and translated by TOM BOTTO. MORE, University of Sussex and PATRICK GOODE. Thirty-three selections from the writings of the Austro-Marxists - notably, Max Adler, Otto Bauer, Rudolf Hilferding, and Karl Renner-are offered here for the first time in English.

$1978 \quad 320$ pp. cloth $\$ 19.95$ paper $\$ 8.50$

\section{MARXISM AND THE METROPOLIS}

New Perspectives in Urban Political Economy

Edited by WILLIAM K. TABB, City University of New York, and LARRY SAWERS, The American University. "A really excellent collection of papers from some of the best young Marxists in the U.S..." -Richard A. Walker, University of California, Berkeley

$1978 \quad 384$ pp. cloth $\$ 10.00 \quad$ paper $\$ 5.50$

\section{POLITICAL PARADOXES AND PUZZLES}

ARUN BOSE, University of Delhi. Drawing on game theory and on the theory of collective choice, Bose provides a well-integrated framework within which to resolve a number of political paradoxes and puzzles, among them, Chinese Communism, capitalist/socialist coexistence, and the balance of global superpower.

1978

$296 \mathrm{pp}$

paper $\$ 5.50$

\section{ARISTOTLE'S}

\section{POLITICAL THEORY}

An Introduction for Students of Political Theory

R.G. MULGAN, University of Otago. "An itluminating and critical guide to what is of general significance and lasting value in Aristotle on politics." -Patrick Romaneli, University of Texas, El Paso $1978 \quad 160 \mathrm{pp}$. cloth $\$ 10.50$ paper $\$ 4.00$

\section{ETHICS, FREE \\ ENTERPRISE, AND PUBLIC POLICY}

Original Essays on Moral Issues in Business

Edited by RICHARD T. DeGEORGE, University of Kansas, and JOSEPH A. PICHLER, University of Kansas School of Business. In eighteen original articles, well-known philosophers, business educators, and industrial and labor leaders of different political positions present their viewpoints on current topics of moral concern, including public sector strikes and advertising.

$1978 \quad 336 \mathrm{pp}$. cloth $\$ 11.00$ paper $\$ 6.00$

\section{CORPORATE AND GOVERNMENTAL DEVIANCE}

Problems of Organizational Behavior in Contemporary Society

Edited by M. DAVID ERMANN, University of Delaware, and RICHARD J. LUNDMAN, Ohio State University. "An intellectually significant as well as an eye-opening inventory of organizational crime and corruption in contemporary America." -Gilbert Geis, University of California, Irvine 1978 $336 \mathrm{pp}$.

paper $\$ 3.50$

\section{A THEORY OF CRIMINAL JUSTICE}

HYMAN GROSS, New York University. "A very good book indeed...A thorough systematic presentation of a general theory of criminal law that is sensitive, original, and persuasive."-loel Feinberg, The Rockefeller University

$1978 \quad 448 \mathrm{pp}$. cloth $\$ 17.50$ paper $\$ 6.00$

\section{THE LIFE AND TIMES OF LIBERAL DEMOCRACY}

C.B. MACPHERSON, University of Toronto. "The most lively and engaging work in political philosophy in the twentieth century. This should cause Liberals and Marxists to reexamine their positions." -George Schedler, Southern Illinois University 1977 (paper, 1978) $120 \mathrm{pp}$. cloth $\$ 6.95$ Prices are subject to change. paper $\$ 2.50$

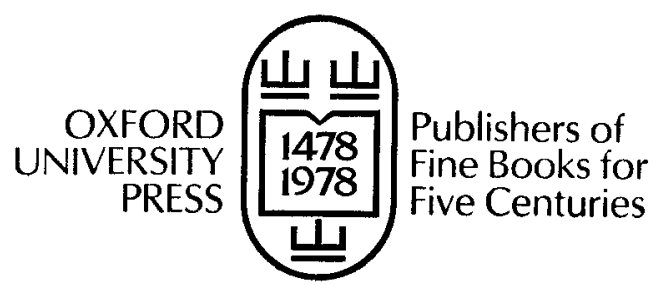

200 Madison Avenue, New York, N.Y. 10016 


\section{American Political Thought:}

The Philosophic Dimension of American Statesmanship

by Morton J. Frisch and Richard G. Stevens, eds. $1976 / 352$ pages/Paper $\$ 5.95$

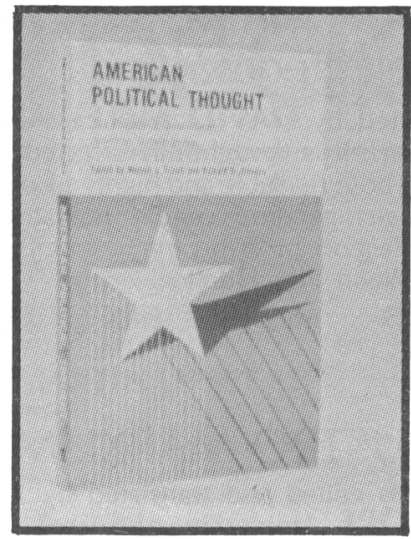

There is evidence of renewed interest in the study of American political thought. That study reaches not only backward to theoretical foundations, but forward to all the questions of American politics. American Political Thought is a unique mixture of the theoretical and the practical, for it is largely the work of our great statesmen. Through the study of American political thought, one can see great democratic statesmen at work, simultaneously adapting principles to circumstances and molding circumstances in the direction of principle.

\section{CONTENTS}

INTRODUCTION/Morton J. Frisch and Richard G. Stevens

THOMAS JEFFERSON/Harvey C. Mansfield. Jr.

THE FEDERALIST/Martin Diamond

JOHN MARSHALL/Robert K. Faulkner

JOHN C. CALHOUN/Ralph Lerner

ABRAHAM LINCOLN/Harry V. Jaffa

FREDERICK DOUGLASS/Herbert $J$. Storing

OLIVER WENDELL HOLMES, JR./Walter Berns

WOODROW WILSON/HarrY Clor

FRANKLIN DELANO ROOSEVELT/Morton J. Frisch

FELIX FRANKFURTER/Richard $G$. Stevens

AMERICAN POLITICAL THOUGHT is ... an outstanding collection of scholarly work, and is far superior in thoughtfulness, depth and incisiveness to any other survey of the subject that has yet been published. The authors have demonstrated that anyone who wishes to understand American politics, and the nature of political life itself, stands much to gain from a serious study of the thought of each of the statesmen that they treat; and their essays constitute a model of how to go about such a study.

Book review, Publius

AMERICAN POLITICAL THOUGHT: The Philosophic Dimension of American Statesmanship edited by Morton J. Frisch and Richard G. Stevens (40158601) 1976/272 pages/Paper/\$5.95

\section{Order your examination copy today!}

Write:

\section{Kendall/Hunt Publishing Company}

K H 2460 Kerper Boulevard

Dubuque, lowa 52001 


\title{
Reconciling Man with the Environment
}

Eric Ashby. "Demonstrating a rare ability to integrate diverse subject matter, Ashby outlines a three-stage 'chain reaction' that he considers essential to the control of an environmental hazard. . . . [His] fusion of environmental, economic, and political considerations is the best this reviewer has seen. The book is nontechnical and brief, yet documented with notes to more detailed sources. Highly recommended."-Library Journal. \$7.95

\section{The Development of the Modern State}

\begin{abstract}
A Sociological Introduction. Gianfranco Poggi. This is a compact analytic survey of the history of the modern state, emphasizing the evolution of its distinctive institutional features. On the basis of a large body of historical, juridical, and sociological literature, much of it not available in English, the author analyzes the feudal system of rule, the late-medieval Ständestaat, the absolutist state, and the constitutional state of the rgth-century. A final chapter discusses major institutional trends in contemporary Western states. \$10.95
\end{abstract}

\section{Pernambuco in the Brazilian Federation, 1889-1937}

Robert M. Levine. The story of Pernambuco, the most important state in Brazil's impoverished Northeast sector, provides a stark case study of a once-important state in political, social, and economic decline-a result of competition from foreign sugar growers, a shift of economic activity southward, and the resistance of the elite to political and economic reforms. In this second of three independent but coordinated studies on Brazilian regionalism, the author traces the shift of power from the centralized Empire to Pernambuco and then follows the course of the Union's gradual assumption of authority and responsibility over the ensuing half century. \$I 7.50

\section{Stanford University Press}




\section{Protest at Selma}

Martin Luther King, Jr., and the Voting Rights Act of 1965

David J. Garrow

The first detailed account of how the Voting Rights Act of I 965 came into being and how the strategy of Martin Luther King, Jr., and the Southern Christian Leadership Conference at Selma won this landmark victory for Southern blacks. This book makes a major new statement on protest activity and the civil rights movement. Illus.

$\$$ I 5.00

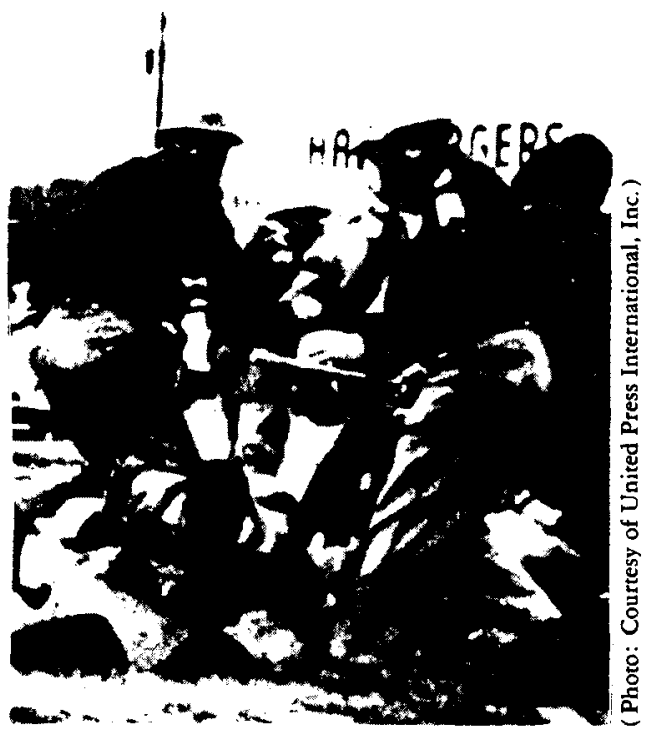

\section{The Presidential Election Game}

Steven J. Brams

In this book Brams applies the tools of modern decision theory and game theory to the analysis of presidential campaigns and elections. His use of scientific modeling to illuminate all aspects of the presidential election process-from state primaries and national conventions to coalition politics and Richard Nixon's resignation-adds a new dimension to our understanding of this important aspect of American politics. Cloth \$ I 5.00 Paper \$3.95

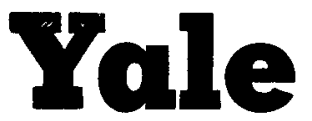

Yale University Press New Haven and London

\section{The Origins of the Second World War}

Maurice Baumont translated by Simone De Couvreur Ferguson

Although the explanations of how and why the Second World War began are fewer and less controversial than those surrounding the origins of the First World War, there are, nevertheless, distinct differences among the perceptions of the nations involved. Until now, the French view has not been definitively presented in English. In this book Maurice Baumont, the dean of French diplomatic historians, expounds that view with clarity and vigor. \$22.00

\section{Southeast Asian Transitions}

\section{Approaches through Social History}

edited by Ruth T. McVey

with the assistance of Adrienne Suddard

In six major essays written to honor the late Harry J. Benda, an international group of scholars focuses on a particular concern of Benda's - the impact of advanced colonialism on Southeast Asian societies and the attempt of the Southeast Asians to develop ideological and institutional responses. The authors have approached the subject from the angle of local history, showing through the study of significant small-scale events how people far from the centers of political power reacted to the pressures for change. $\$ 17.5^{\circ}$

\section{Quaker Experiences in International Conciliation}

\section{H. Mike Yarrow}

Foreword by Anatol Rapaport

As far back as the early I 900 s, the Quakers have been engaged in a program of quiet private diplomacy that won them a Nobel peace prize in I 947. During the turbulent 1960 s, they acted as unofficial conciliators in several tense situations. This comprehensive study of Quaker peace-making activities focuses primarily on the variety and effectiveness of their efforts in Berlin from 1960 to 1973 , in India/Pakistan in 1965 , and in Nigeria from 1967 to 1970 . \$10.00 


\section{Distinguished new books from S.Martins Press}

\section{Farewell to Revolution}

Marxist Philosophy and the Modern World

S.F. Kissin

In his incisive study of the similarities between Marxism and religion, S.F. Kissin establishes objective criteria necessary to distinguish between religious creeds and secular ideologies and analyzes the demands of belief and practice of Marxism, particularly in the Soviet Union. Mr. Kissin's often startling conclusions-that Marxism is not a rational philosophy but a quasi-religion; that the Soviet oriented communists are not revolutionaries but revisionist moderates-collectively offer a powerful challenge that traditional Marxist thought cannot ignore.

October 1978

ISBN 0-312-28267-2

approx. 200 pages

$\$ 16.95$

\section{Federal Solutions to European Issues}

Bernard Burrows, Geoffrey Denton,

and Geoffrey Edwards, editors

This collection of papers by a group of eminent academic and international civil servants-not all of whom are confirmed "federalists"-looks realistically at the social, political, institutional, economic, and industrial issues that beset the complex industrial societies of Western Europe. Their studies assess the merits of federalism and the degree to which such a division of powers, responsibilities and functions already exists. The approach of the contributors is often radical, but the solutions they propose are soundly based on practical politics.

September 1978

ISBN 0-312-28546-9

approx. 240 pages

\section{Human Rights}

Eugene Kamenka and Alice Enr-Soon Tay, editors Ideas and Idelogies Series

The theoretical concept of human rights-a concept which implies a general view of man and society, of individuality, of politics and the ends of government-is a historical idea, its internal complexities, the variations in its definition among political ideologies, the ethical dilemmas involved in the conflict between individual and group rights, and the legal and social significance of human rights in the international order.

September 1978 ISBN 0-312-39960-X 144 pages $\$ 16.50$

\section{Population Decline in Europe}

Implications of a Declining or Stationary Population

Council of Europe, editor

These eleven essays, read at the 1976 Council of Europe's Seminar on the Implications of Stationary or Declining Populations and published here for the first time, explore the problems created by the recent profound shift in European demographic trends. The papers cover a wide range of topics such as the economic aspects of population, the sociology and micro-economics of the family, migration. demographic aspects of the labor force, and probable developments in the social services affected by changes in population and age structure.

August 1978

ISBN 0-312-6325-1

300 pages, charts and tables

\section{China's Role in World Affairs \\ Michael B. Yahuda}

China's status in world affairs is unique: it is the only country with the power to alter decisively the strategic balance of power between the United States and Russia. This book discusses China's roles as ally of the Soviet Union and as an independent socialist system following their diplomatic rupture. Perhaps most important to Professor Yahuda's analysis is his exploration of the origin and place of Third World states in China's global perspectives. October 1978 ISBN 0-312-13358-8 336 pages $\$ 18.95$

\section{Law and Society \\ The Crisis in Legal Ideals \\ Eugene Kamenka, Robert Brown and \\ Alice Ehr-Soon Tay, editors \\ Ideas and Ideologies Series}

The profound legal and judicial implications of a recent and dramatic shift in the tone and style of public life in western, industrialized societies are the subject of the symposium which contributed this volume. The contributors probe the changing balance in the tension between the concepts of freedom and determinism, between the individual and the community. Their essays trace these conflicting ideals through contemporary legal philosophy and popular perceptions of the law as well as through changing concepts of property, rights and welfare, criminology and penology. October 1978

ISBN 0-312-47545-4 approx. 135 pages $\$ 17.50$

\section{Portugal \\ Birth of a Democracy \\ Robert Harvey}

Robert Harvey, journalist and scholar, has written the inside story of the tumultuous struggle for Portugal's freedom, from the 1974 military coup through the installation of a democractic government in 1976 , to the present. Derived from the author's personal conversations with most of the leading protagonists in the events, this book reveals for the first time the origins and history of the moderate backlash within the army led by General (now President) Eames - an action which prevented the imposition of a military dictatorship and eventually paved the way for the establishment of a democracy.

October 1978 ISBN 0-312-63184-7 200 pages $\$ 19.95$

\section{The State, Law and Development Robert B. Seidman}

This original work presents a theory of the capacities and the limitations of the state and the law to solve the problems of poverty and oppression. Having set forth his theory of the relationship between the state, the legal order, and economic development, Professor Seidman explores that theory in the context of Anglophonic Africa. The failure of African legal order to effect development, he argues, is an institutional failure; the result of the contradiction between authoritarian structures of the state and legal order and the participatory requirements of induced social change.

October 1978 ISBN 0-312-75613-5 320 pages $\$ 27.50$ 
THE SOVIET THREAT

Myths and Realities

Edited by CRAYSON KIRK and NILS WESSELL.

ca. 792 pp. July 1978 LC 78-56914 ISBN 0-03-046591-5 \$16.95

\title{
ROMANIAN FOREIGN POLICY SINCE 1965
}

The Political and Military Limits of Autonomy AUREL BRAUN

236 pp. August 1978 LC 78.9516 ISBN 0.03-043471-8 ca. $\$ 18.95$

\section{SOVIET FOREIGN POLICY TOWARD WESTERN EUROPE \\ Edited by CEORGE GINSBURGS and AIVIN Z. RUBINSTEIN}

ca. 280 pp. Sept. 1978 LC 78.17925 ISBN 0.03-044331-8 ca. $\$ 20.00$

\section{FOREIGN POLICY MAKING IN WESTERN EUROPE \\ A Comparative Approach}

Edited by WILLIAM WALLACE and W.E. PATERSON

$\begin{array}{llll}\text { ca. } 200 \text { pp. August } 1978 \text { LC 78-58844 ISBN 0.03-046271.1 Ca. } \$ 20.00 & 0\end{array}$

\author{
PEOPLE AND PARLIAMENT \\ Edited by JOHN P. MACINTOSH \\ ca. 200 pp. Sept 1978 LC $78-60433$ ISBN 0-03-046231.2 ca. $\$ 18.00$
}

\section{INTERNATIONAL CRISES AND CRISIS REPORTING \\ An East-West Symposium \\ Edited by DANIEL FREI \\ ca. 155 pp. August 1978 LC 78-58474 ISBN 0-03-046346-7 ca. $\$ 21.95$}

THE PRESIDENTIAL DEBATES OF 1976

Perspectives and Promise

Edited by GEORCE F. BISHOP, ROBERT G. MEADOW. and MARILYN IACKSON-BEECK

ca. 400 pp. Sept. 1978 ISBN 0-03-044271-0 ca. $\$ 25.00$

\section{MEXICAN DEMOCRACY: A CRITICAL VIEW \\ Revised Edition \\ KENNETH F. IOHNSON \\ 304 pp August 1978 LC 77.83473 15BN 0-03-027711-6 ca $\$ 18.95$ PSS Student Edition: ISBN 0-03-028151-2 ca. $\$ 5.95$}

PRAEGER SPECIAL STUDIES • PRAEGER PUBLISHERS

A Division of HOLT, RINEHART AND WINSTON, CBS PUBLISHING GROUP 383 Madison Avenue, New York, N.Y. 10017

Prices are subject to change without notice

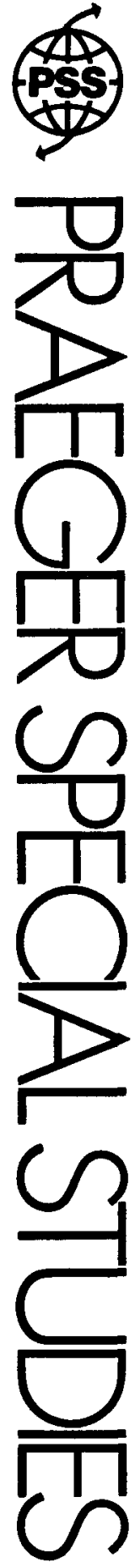




\section{CLASSICS IN COMPARATIVE, CONSTITUTIONAL \& INTERNATIONAL PUBLIC LAW}

Edited with Introductions by Richard M. Pious, Barnard College, Columbia University

\section{John W. Burgess \\ 1 POLITICAL SCIENCE AND COMPARATIVE CONSTITUTIONAL LAW: \\ Selections}

Burgess's book produced the classic statement on American public law, expounded his unique interpretations of the Constitution, and offered a view of the governmental process Immediately prior to the work of Woodrow Wilson and Arthur Bentley. (1890)

Just Published

ISBN: 0-89561-063-9

Cloth, $\$ 15.00$

Thomas M. Cooley

THE GENERAL PRINCIPLES OF CONSTITUTIONAL LAW

IN THE UNITED STATES OF AMERICA

Cooley's articulation of the assumptions of the laissez-faire jurists about the nature of the American political system has proved remarkably prophetic of the reemergence of a conservative political movement in the late 1970's. (1880)

Just Published

ISBN: 0-89561-064-7

Cloth, $\$ 15.00$

Frank Goodnow / COMPARATIVE ADMINISTRATIVE LAW

Goodnow established administrative law as separate field of study; he placed the role of the governmental official in a perspective that anticipated today's problems of administrative discretion with respect to the executive branch. (1893)

Just Published

ISBN: 0-89561-065-5

Cloth, $\$ 15.00$

\section{Henry C. Lockwood / THE ABOLITION OF THE PRESIDENCY}

Lockwood's bestselling book carried Whiggery to its logical conclusion. His plan for a council of state reflects, in remarkable detall, basic constitutional debates between the executive and the legislative areas of government that continue today. (1884)

Just Published

ISBN: 0-89561-066-3

Cloth, $\$ 15.00$

\section{Sir Henry Maine/ INTERNATIONAL LAW}

Maine hoped that war, though unavoldable, might be fought humanely, and that peace might be found through collective security arrangements rather than international organizations which he abhored. (1888)

Just Published

ISBN: 0-89561-067-1

Cloth, $\$ 15.00$

\section{6} THE UNWRITTEN CONSTITUTION OF THE UNITED STATES

Tledeman brilliantly develops the theory of the unwritten constitution, based on "the prevalent sense of right," that should be used by jurists to construe the powers and ilmits of all levels of government. (1890)

Juat Published

ISBN: 0-89561-068-X

Cloth, $\$ 15.00$

\section{7}

\section{Woodrow Wilson / THE STATE}

Considered the first actual text in comparative politics, The State systematically, historlcally, and comparatively describes the political systems of antiquity, modern Europe, and the United States, and is a classic example of the institutional approach to polltical analysls. (1888)

Just Published

ISBN: 0-89561-069-8

Cloth, $\$ 15.00$

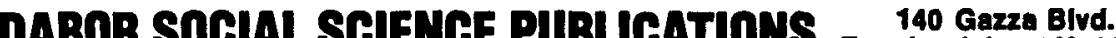

Farmingdale, N.Y. 11735 516-293-3350

Name.

Address

city

Individuals please enclose check or money order, Institutions may enclose purchase order for bliling.

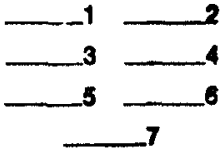




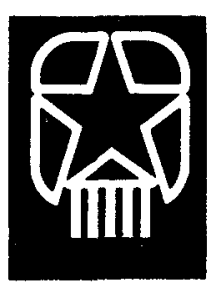

\section{Supplementary Empirical Teaching Units in Political Science:}

New computer related instructional materials whereby students learn important substantive topics in American politics as they learn methods of analysis.

\section{Eight SETUPS: American Politics}

Are Available Now for Class Use

1. Voting Behavior: The 1972 Election by Bruce D. Bowen, C. Anthony Broh, Charles L. Prysby.

2. Political Socialization Across the Generations by Paul Allen Beck, Jere W. Bruner, L. Douglas Dobson.

3. Political Participation by F. Christopher Arterton, Harlan Hahn.

4. The Supreme Court in American Politics: Policy Through Law by John Paul Ryan, C. Neal Tate.

5. U.S. Energy, Environment and Economic Problems: A Public Policy Simulation by Barry Hughes.

6. Representation in the United States Congress: 1973 by Ray A. Geigle and Peter J. Hartjens.

7. The Dynamics of Political Budgeting: A Public Policy Simulation by Marvin K. Hoffman.

8. The Fear of Crime by Wesley G. Skogan and William R. Klecka. 


\section{Four SETUPS: Cross-National and World Politics Are Now Available for Class Use}

1. Comparative Voting Behavior by Herbert B. Asher, Bradley Richardson.

2. Comparative Budgeting: Policy and Process by John Creighton Campbell and John M. Echols.

3. The Arab-Israeli Conflict: A Decision-Making Game by Karen Ann Feste. 4. Are Political Values Really Changing? by Charles Taylor.

Each SETUPS is a module that can be taught in one to two weeks. SETUPS were designed to supplement instruction in introductory courses. But SETUPS have been field tested successfully in upper division courses. SETUPS were developed by faculty in workshops supported by a grant from the National Science Foundation to the American Political Science Association and hosted by the Inter-University Consortium for Political and Social Research, summer, 1974 and summer 1975.

\section{Each SETUPS Module Includes a Monograph and a Data Set}

The monograph is a $5 \frac{112}{2}$ " $18 \frac{1}{2}$ " paperback of approximately 100 pages with:

1. A substantive essay on the topic.

2. Analytical exercises.

3. Instructions about how to do the exercises.

4. Suggestions for further readings and exercises.

5. A code book for the data set.

The data sets are prepared and distributed by the Inter-University Consortium for Political and Social Research. SETUPS data can be ordered for use with SPSS, OSIRIS or as card image.

Each SETUPS will cost $\$ 3.50$. Lower prices are arranged for bulk orders. An order for 25 or more SETUPS will entitle you to the data sets for all the SETUPS at no extra charge.

\section{To Order SETUPS}

Order the SETUPS monographs from the American Political Science Association through your bookstore. Ask your bookstore to include your name when they place the SETUPS order with APSA. When we confirm the bookstore order, we shall send you a data-specification form if your school does not have the SETUPS data set already. 


\section{TEXTBOOKS FROM CQ PRESS}

Politics and Public Policy Series

Robert L. Peabody, Johns Hopkins University - Advisory Editor

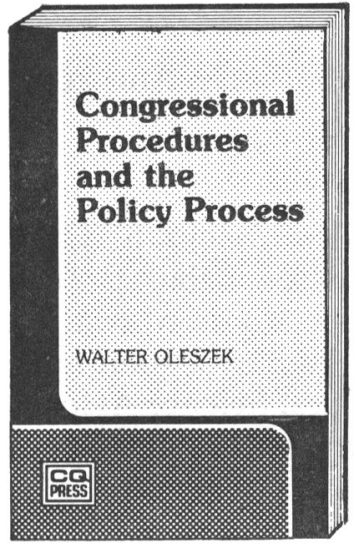

Congressional

Procedures and the Policy Process

by Walter J. Oleszek

Congressional Procedures and the Policy Process examines the process in Congress that transforms an idea into national policy. It illustrates how rules and procedures permeate the legislative process - how rules both affect and are affected by policy goals and outcomes. The major changes in Congress in the 1970s are examined, as well as the congressional environment, the formulation of legislation and its consideration by committees, scheduling and floor action, conference committee action, and oversight. The text ( 218 pages) is accompanied by a glossary of terms.

August 1978256 pages $\$ 4.75$ Illustrations, Bibliography

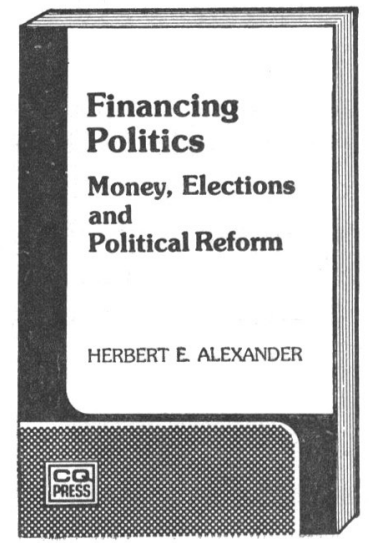

\section{Financing Politics:} Money, Elections and Political Reform

by Herbert E. Alexander

Financing Politics is a thorough introduction to this important subject. It focuses on the increasing cost of campaigns, contributions by organizations, and public funding of presidential campaigns. Major election reform legislation is examined, along with analyses of campaign finance in the 1972, 1974, and 1976 elections.

An excellent book for courses on campaigns and elections, political parties, and interest groups.

1976299 pages $\$ 4.75$ Bibliography and Appendix

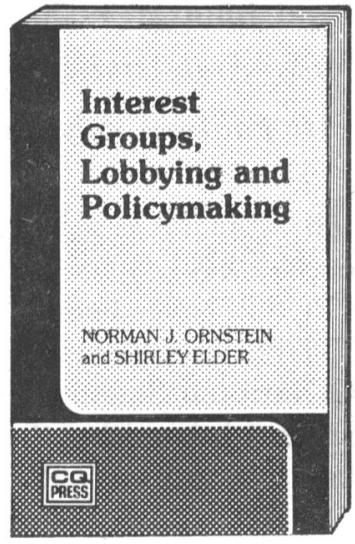

Interest Groups, Lobbying and Policymaking by Norman J. Ornstein and Shirley Elder

Interest Groups, Lobbying and Policymaking combines an analysis of interest groups and their operations with three lively case studies of lobbying in action. Norman Ornstein examines general theories about groups and then goes on to describe the types, purposes, resources, tactics, and regulation of Washington lobbies. Shirley Elder contributes the three case studies Common-Site Picketing, Clean Air Legislation, and the B-1 Bomber.

This book will be Invaluable In courses on interest groups, public policy, legislative process, and American government.

August 1978245 pages $\$ 4.75$ Bibliography

If you would like to consider these books for course adoption write for a complimentary copy to:

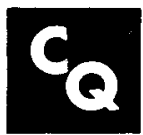

Ms. Patricia Silver, College Services Representative

Congressional Quarterly Inc.

1414 22nd St., N.W., Washington, D.C. 20037 


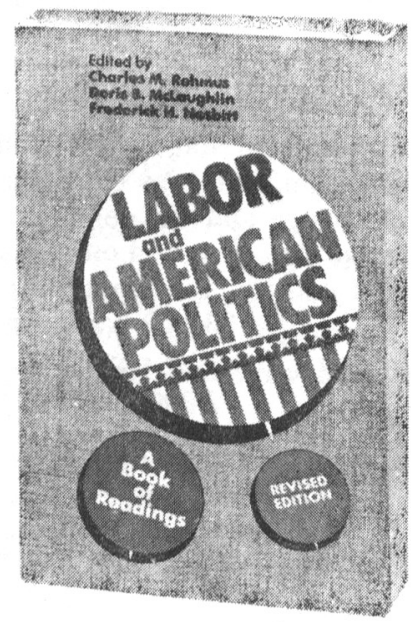

$\$ 15.00$

paperbound $\$ 7.95$
LABOR and AMERICAN POLITICS

A BOOK OF READINGS REVISED EDITION

Edited by

Charles M. Rehmus

Doris B. McLaughlin

Frederick H. Nesbitt

\section{THE UNIVERSITY OF MICHIGAN PRESS \\ P.O. Box 1104 Ann Arbor, Michigan 48106}

International Political Science Association

\section{FAR EASTERN POLITICS}

$$
\text { CHINA - JAPAN - KOREA - 1950-1975 }
$$

\section{Compiled by Anthony Ferguson}

Asian Librarian - Harold B. Lee Library - Brigham Young University

235 pages, soft covers, $\$ 12.50$

ISBN 2-902565-01-1

This volume is a special index to International Political Science Abstracts, vols. 1 to 25. It provides, for each entry, full bibliographic references, as well as the abstract number for the benefit of readers who have access to IPSA. Titles of articles in languages other than English have been translated. Arrangement is by countries with subject matter subdivisions; there are additional subject and author indexes.

Orders: IPSA, 27, RUE SAINT-GUILLAUME, 75007 PARIS, FRANCE or: IPSA,

C/O UNIVERSITY OF OTTAWA, OTTAWA KIN 6N5, CANADA 


\section{The Breakdown of Democratic Regimes}

edited by Juan J. Linz and Alfred Stepan

In a systematic review of the political experiences of European and Latin American democratic nations, these thought-provoking books provide a significant new comparative framework for understanding the dynamics of political change and the conditions necessary for democratic stability. For anyone-student, scholar, or concerned citizenpondering the events of recent history or the future of world politics, The Breakdown of Democratic Regimes is crucial reading.

$\$ 35.00$ hardcover

The Breakdown of Democratic Regimes is available in a single hardcover volume and as four separate paperbacks suitable for course use.

Crisis, Breakdown, and Reequilibration

Volume 1

Juan J. Linz

$\$ 2.95$ paperback

Europe

Volume 2

edited by Juan J. Linz and Alfred Stepan

$\$ 3.95$ paperback

\section{Latin America}

Volume 3

edited by Juan J. Linz and Alfred Stepan

$\$ 3.95$ paperback

Chile

Volume 4

Arturo Valenzuela

$\$ 3.95$ paperback

\section{Women under Communism}

Barbara Wolfe Jancar

For those who believe that communism has emancipated woman and given her an equal place in society, this book is an eye-opener. Comparative and interdisciplinary in approach, it reveals that sexual stereotyping and all its consequences prevail in the communist nations of Central and Eastern Europe, in China, and in Cuba. $\$ 16.00$

\section{The Making of a Missile Crisis}

October 1962

Herbert S. Dinerstein

Now in paperback, with a new appendix containing a recently declassified letter written by Nikita Khrushchev at the height of the missile crisis

"This study is a bold and imaginative work of scholarship which makes an important contribution to the literature on the Cuban missile crisis and to the study of foreign policy in general." - American Political Science Review "Outstanding and indispensable." - Perspective $\$ 4.95$ paperback; $\$ 16.50$ hardcover

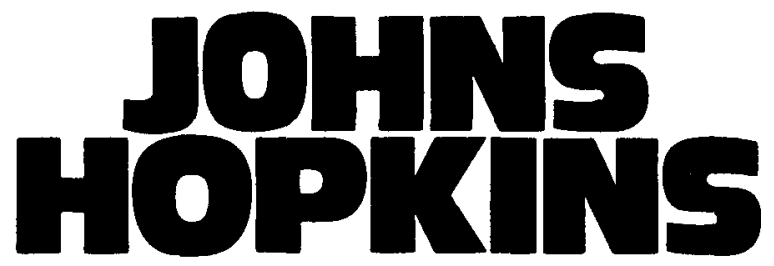

The Johns Hopkins University Press • Baltimore, Maryland 21218 
Goodbye to Good-Time Charlie

The American Governor Transformed, 1950-1975

Larry Sabato, Oxford University

304 pp. LC 78-333 $\$ 20.00$

ISBN 0-669-02161-x

Minority Admissions

Robert L. Bailey, in collaboration with

Anne L. Hafner, University of California

Foreword by Patrick Morgan

240 pp. LC 77.18360 $\$ 18.00$

ISBN 0669-02095-8

The Codetermination Movement in the West

Labor Participation in the Management of

Business Firms

edited by Svetozar Pejovich, University

of Dallas

208 pp. LC 77-18480 $\$ 18.00$

ISBN 0-669-02112-1

Pressure Politics in Contemporary Britain

Graham Wootton, Tufts University

272 pp. LC 77-26372 \$19.95

ISBN 0-669-02167-9

Big Business and the Mass Media

Bernard Rubin and Associates

Boston University

192 pp. LC 77-2516 \$16.50

ISBN 0-669-01517-2

Judicial Impacts and State Supreme Courts George Alan Tarr, St. Olaf College

192 pp. LC $77.228 \quad \$ 18.00$

ISBN 0-669-01434-6

The Criminal Court

How it Works

Roberta Rovner-Pieczenik, The Police

Foundation

144 pp. LC 76-01056-1 $\$ 12.50$

ISBN 0-669-01056-1

The Jurocracy

Government Lawyers, Agency Programs, and Judicial Decisions

Donald L. Horowitz

160 pp. LC 76-27921 $\$ 14.00$

ISBN 0-669-00986-5

State of the Nation III

William Watts, Lloyd A. Free,

Potomac Associates

256 pp. LC 77-18653 $\$ 13.50$

ISBN 0-669-01507-5

The Voluntary Nonprofit Sector

An Economic Analysis

Burton A. Weisbrod, University of Wisconsin

208 pp. LC $77.9132 \$ \$ 18.00$

ISBN 0-669-01772-8

Democracy and the Amendments to the Constitution

Alan P. Grimes, Michigan State University

Now Available LC 78-4342

ISBN 0-669-02344-2

Citizen Participation in America

Essays on the State of the Art

edited by Stuart Langton, The Lincoln

Filene Center, Tufts University

September LC 78-19913

ISBN 0-669-02465-1

Teaching Policy Studies

What and How

edited by William D. Coplin,

Syracuse University

A Policy Studies Organization Book

$240 \mathrm{pp}$. LC $77.9186 \quad \$ 17.00$

ISBN 0-669-01829-5

Legislative Reform

The Policy Impact

edited by Leroy N. Rieselbach,

Indiana University

A Policy Studies Organization Book

Now Available LC 77.223

ISBN 0-669-01436-2

Regional Impacts of Federal Fiscal Policy

Theory and Praxis

Thanos Catsambas, Yale University

Now Available LC 77-12282

ISBN 0-669-01953-4

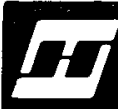

HEATH
Lexington Books

D. C. Heath and Company

125 Spring Street

Lexington, MA 02173

(212) $924-6460$ (617) 862-6650

Call our toll-free number

(800) 428-9292 


\section{Congress and the Budget}

mentation of the Congressional Budget Act of 1974, Mr. ally available to an insider with the (Crisp andinformative.... objectivity of the outsider." - Sen. EdmundS. Muskie "Cr

Alice Rivlin, Director, Congressional Budget Office

$\$ 12.95$

256 pages

\section{Citizens and the Enviromment}

Case Studies in Popular Action

By Lynton K. Caldwell, Lynton R. Hayes, and isabel M. MacWhirter studies inminating the contict betwable for courses in enviand . relationship between government and the people in afree but very ciety." - Planning paper $\$ 6.95$ cloth $\$ 17.50$ 480 pages

\section{Partics and Dlections in an Anti-Party Age}

American Politics and the Crisis of Confidence

Edited with an Introduction by Jeff Fishel Contains an extremely wide range of new and reprinted essays by distical parties and the itical scientists on the current condition offers solutions. An essential text for electoral process. Delineates problems; offers solutions. An clectoral in contemporary American government and $\mathbf{\$ 8 . 9 5}$ cloth $\$ 25.00$ 384 pages

\section{On the Take}

From Petty Crooks to Presidents

By William S. Chambliss

of subterranean world that surrounds the billion-dollar industry The story of the sublerranean wor gambling, drugs, usury, and graft. Beginning built on such criminal activittes Washington, Chambliss shows how with a detailed study of Seatle, Wan business and political interest 288 pages

\section{A Short History of the Vietuam War}

Edited by Allan R. Milletf
Foreword by Major General Edward G. Lansdale, USAF, Ret.
Ams confusion of American intervention in Vietnam is fraught with lessons reality. This concise, ends and means, goals and methods, and rhe understanding the conflict and wid teachers and students in understanding the war. accurate history will aid teachers andes a detailed chronology of the wath $\$ 12.50$
paper $\$ 3.95$ cloth $\$$ 192 pages 


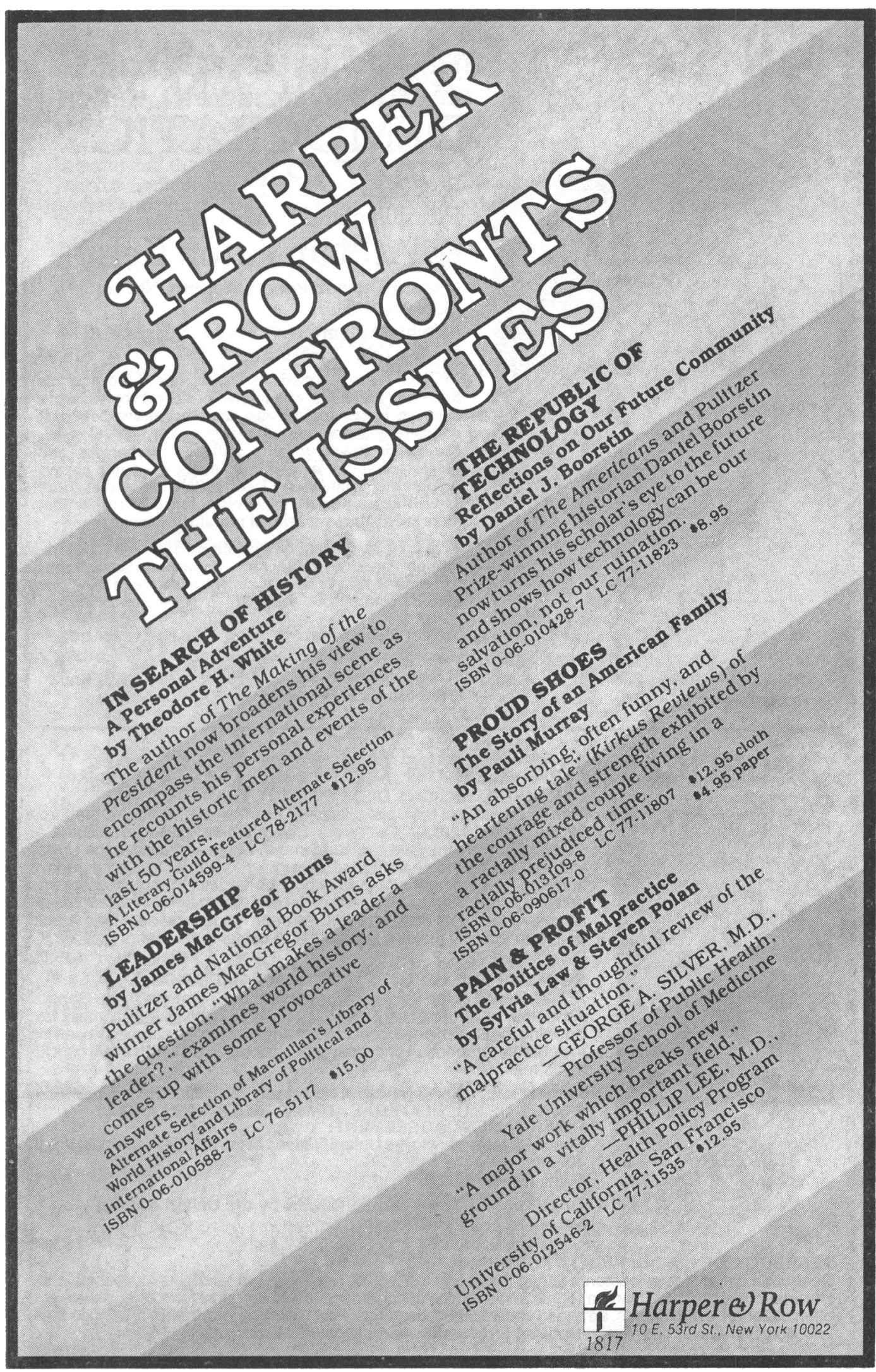



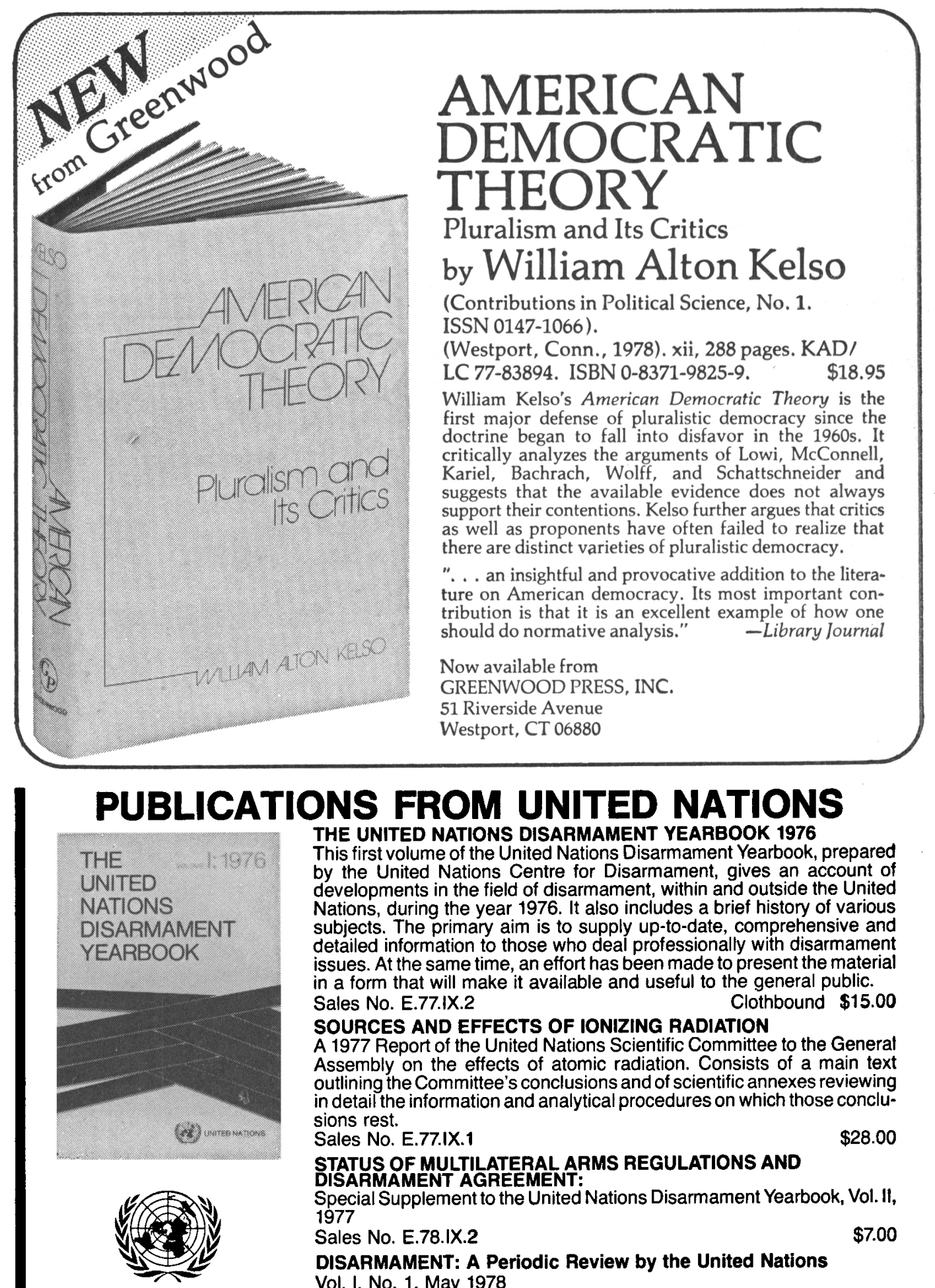

\section{ONS FROM UNITED NATIONS \\ THE UNITED NATIONS DISARMAMENT YEARBOOK 1976}

This first volume of the United Nations Disarmament Yearbook, prepared by the United Nations Centre for Disarmament, gives an account of developments in the field of disarmament, within and outside the United Nations, during the year 1976. It also includes a brief history of various subjects. The primary aim is to supply up-to-date, comprehensive and detailed information to those who deal professionally with disarmament issues. At the same time, an effort has been made to present the material in a form that will make it available and useful to the general public.

Sales No. E.77.1X.2

Clothbound $\$ 15.00$

\section{SOURCES AND EFFECTS OF IONIZING RADIATION}

A 1977 Report of the United Nations Scientific Committee to the General Assembly on the effects of atomic radiation. Consists of a main text outlining the Committee's conclusions and of scientific annexes reviewing in detail the information and analytical procedures on which those conclusions rest.

Sales No. E.77.IX.1

$\$ 28.00$

\section{STATUS OF MULTILATERAL ARMS REGULATIONS AND \\ DISARMAMENT AGREEMENT:}

Special Supplement to the United Nations Disarmament Yearbook, Vol.II, 1977

Sales No. E.78.IX.2

DISARMAMENT: A Periodic Review by the United Nations

Vol. I, No. 1, May 1978

Sales No. E.78.IX.3

YEARBOOK OF HUMAN RIGHTS FOR 1973-1974

Deals with national developments during the period 1973-1974 relating to human rights as defined in the Universal Declaration of Human Rights and contains concise accounts in narrative form of legislative and other national developments, arranged under subject headings. Part I contains information relating to Trust and Non-Self-Governing Territories; Part II concerns international developments.

Sales No. E.76.XIV.1

$\$ 15.00$ 


\section{Main Currents of Marxism \\ Its Rise, Growth and Dissolution}

LESZEK KOLAKOWSKI; translated by P.S. FALLA. A handbook and thorough survey of the varieties of Marxism, Main Currents of Marxism delineates the development of Marx's own thought and the contributions of his best-known followers. No survey of the doctrines of the Marxist tradition could fail to be controversial but Professor Kolakowski's treatment is detached and pluralistic and he does not attempt to identify a pure or essentially Marxist stand in the tradition as a whole.

Volume I: The Founders September 1978

Volume II: The Golden Age September 1978

Volume III: The Breakdown September 1978

$480 \mathrm{pp}$.

$592 \mathrm{pp}$.

$592 \mathrm{pp}$.
$\$ 19.50$

$\$ 19.95$

$\$ 19.95$

\section{Conflict and Democracy}

\section{Studies in Trade Union Government}

JOHN HEMINCWAY. This study analyzes earlier theories of internal trade union government and democracy and suggests a more comprehensive model based on bargaining between leaders and members to resolve conflicts. With the empirical support of three detailed studies of the bargaining process, the book develops this model and suggests that assessment of "democracy" must be reserved for moral rather than empirical judgment.

1978

$192 \mathrm{pp}$.

$\$ 15.50$

\section{Urban Planning in Rich and Poor Countries}

HUGH STRETTON. Hugh Stretton argues that a rational approach to urban planning should be based on an understanding of the complexities of societies and their economic and political structure. He examines in detail the post-war urban development of capitalist and communist societies, rich and poor, analyzes their successes and failures, and suggests a direction for a more level-headed approach to planning in the future.
Fall 1978
$200 \mathrm{pp}$.
cloth $\$ 10.95$ paper $\$ 5.50$

\section{International Crises and the Role of Law}

These two volumes complete the series of studies, published in collaboration with the American Society of International Law, which consider the role of international law in government decision-making during some of the political crises of recent years.

\section{Points of Choice}

ROGER FISHER, Harvard University

1978

$100 \mathrm{pp}$.

paper $\$ 4.95$

The United Nations Operation in the Congo 1960-1964

\section{GEORGES ABI-SAAB}

1978

200 pp.; map

paper $\$ 6.50$

Prices and publication dates are subject to change.

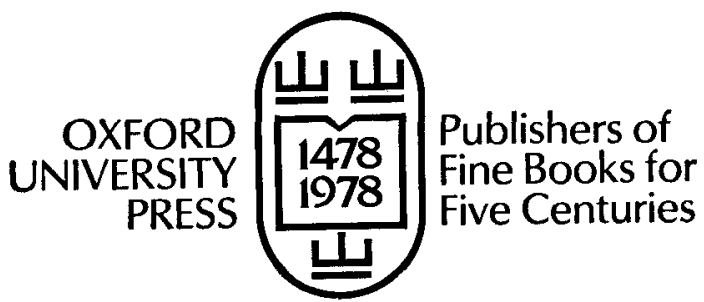

200 Madison Avenue, New York, New York 10016 


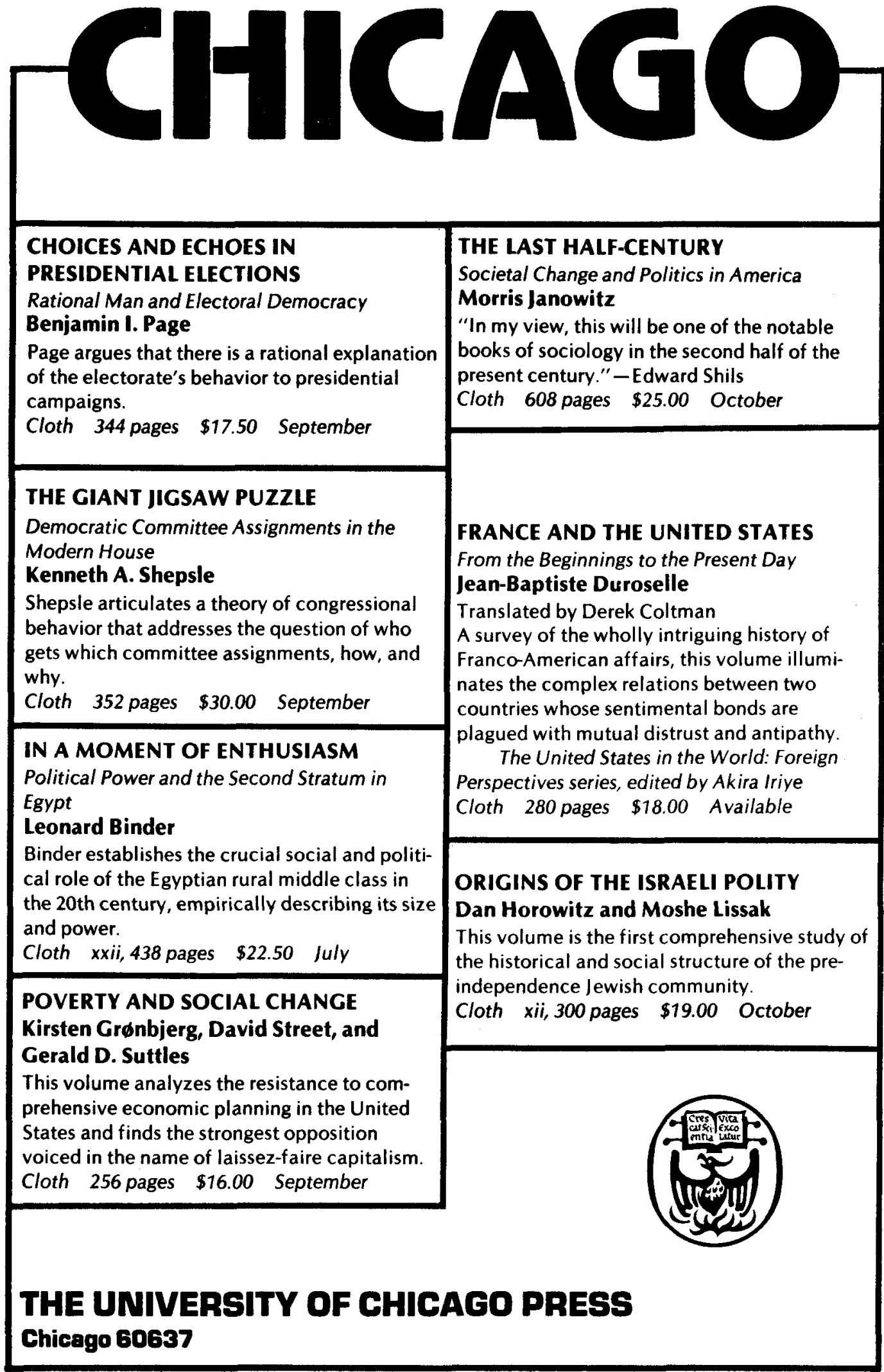




\section{GOVERNMENT REGULATION OF HIGHER EDUCATION \\ Edited by Walter C. Hobbs, SUNY, Buffalo}

This book examines the incursion of government regulation among colleges and universities-from the perspectives of the legal scholar, the university president, the university lawyer, the government lawyer, the university's Affirmative Action officer, the professional association's government watchdog, and the academic scholar-statesman.

$\$ 15.00$

\section{THE FEDERAL INTEREST IN FINANCING SCHOOLING \\ Michael P. Timpane, The Rand Corporation}

Timpane offers a systematic review and synthesis of the issues surrounding the definition and implementation of federal involvement in education. Written by researchers, legislative aides and policy analysts involved in the Washington education policy debate, the discussions of these issues highlight definitive policy directions for the development of a more coherent and effective federal role in the financing of schooling.

ca. $\$ 16.50$

\section{ENERGY AND THE COMMUNITY}

Rayond Burby and Fleming A. Bell, Center for Urban and Regional Studies

Drawing from reports of research and observation in many areas of energy conservation and consumption, Energy and the Community discusses the best ways to adapt to changes in energy supplies and prices.

ca. $\$ 17.50$

\section{NUCLEAR ENERGY AND ALTERNATIVES}

Proceedings of the International Scientific Forum on an Acceptable Nuclear Energy Future of the World Edited by Arnold Perlmutter, Osman K. Kadiroglu and Linda Scott, University of Miami

(Published for the Center for Theoretical Studies) Report of a forum sponsored by the Center for Theoretical Studies to consider future global energy requirements and world developments to meet this demand, including the most desirable role for plutonium and other fuel cycles; thermo-nuclear, geothermal, coal and solar energy, and the availability of oil and gas.

ca. $\$ 25.00$

\section{ALTERNATIVES TO GROWTH}

Edited by Dennis Meadows, Dartmouth College Papers from the 1975 Alternatives to Growth competition and conference questioning how society can 1 provide a good life for citizens without ever-increasing | population growth, energy resource use, and physical output.

Cloth-\$16.50, Paper-\$7.95

\section{STALEMATE IN TECHNOLOGY}

Gerhard Mensch, International Institute of

Management, Berlin

Originally published in Germany, this much acclaimed book links worldwide economic cycles-periods of growth and affluence as well as periods of recessionwith innovations (or the lack of innovation) in technology. It offers convincing evidence of the need for constructive government policies which encourage research and development of basic innovations in new areas.

In preparation

ca. $\$ 15.00$
PATTERNS OF METROPOLITAN POLICING

Elinor Ostrom and Roger B. Parks, Indiana

University; Gordon Whitaker, University of North

Carolina

This book identifies and describes the diverse patterns in policing arrangements throughout metropolitan America, and offers empirical evidence for planning future policies.

$\$ 18.00$

\section{THE COURTROOM ELITE}

An Organizational Perspective on Criminal Justice Peter F. Nardulli, University of lllinois

A proposal for a felony disposition model for criminal justice which would fundamentally change the interest and power structures of participants in the dispositional process of the criminal courts.

In preparation

ca. $\$ 16.50$

\section{MILITARY EXPENDITURE LIMITATION FOR} ARMS CONTROL: PROBLEMS AND PROSPECTS With a Documentary History of Recent Proposals Abraham S. Becker, The Rand Corporation

Economic, military and political issues which must be solved if expenditure limitation agreements among the major powers are to become a serious possibility. $\$ 17.50$

\section{PROPERTY TAXATION}

The Need for Reform

Karl E. Case, II, Wellesley College

A comprehensive analysis of the occurrence, causes and consequences of inaccurate assessment in the United States, this study offers valuable new data documenting the extent of assessment errors. It also analyzes the sources of assessment errors and how they affect property values. The book concludes with a number of specific suggestions for reform.

ca. $\$ 15.00$

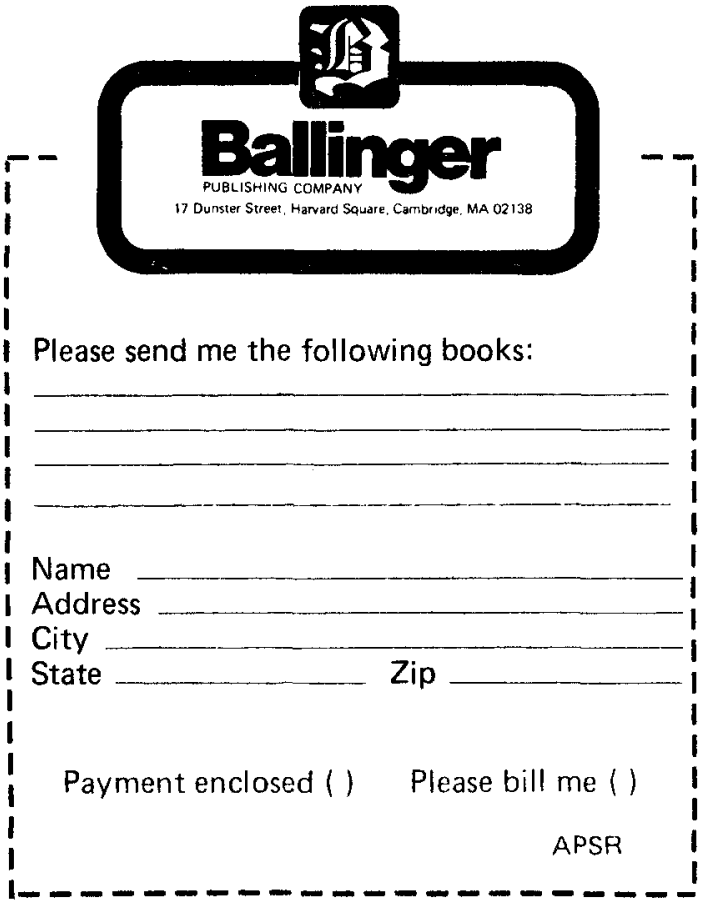




\section{Listing and Order Form for Publications of the AMERICAN POLITICAL SCIENCE ASSOCIATION}

THE AMERICAN POLITICAL SCIENCE REVIEW. Quarterly journal of scholarly articles and book reviews in political science. Included in APSA membership. Back issues: $\$ 10.50$ per copy; $\$ 42.00$ per volume.

PS. Quarterly journal of Association news and articles of professional concern. Included in APSA membership. Back issues: $\$ 2.00$ per copy; $\$ 8.00$ per volume. $(\$ 5.00$ for the Spring issue containing the preliminary program.)

DEA NEWS FOR TEACHERS OF POLITICAL SCIENCE. Newspaper on education and the curriculum. Included in APSA membership.

ANNUAL MEeting PROgRaM. Final, program for APSA Annual Meeting. Included in Annual Meeting Registration. Extra copies: $\$ 1.50$.

APSA ANNUAL MEETING PAPERS.** Hard copies, $\$ 3.00$ each.

APSA ANNUAL MEETING PROCEEDINGS.** Microfilm reels of all papers, 1901-1912; 1956-present. \$22.00 per reel (approx. 7 reels per meeting).

CUMULATIVE INDEX TO THE AMERICAN POLITICAL SCIENCE REVIEW.** 1906-1968, \$6.50.

CUMULATIVE INDEX TO THE PROCEEDINGS OF THE ANNUAL MEETINGS." Key word index to all papers included in proceedings of Annual Meetings for $1904.1912 ; 1956.1970 ; \$ 18.50$.

WOMEN IN POLITICAL SCIENCE: STUDIES AND REPORTS, 1967.71 OF THE APSA COMMITTEE ON THE STATUS OF WOMEN IN THE PROFESSION.** PB 486, $\$ 6.00$ microfilm; $\$ 16.50$ Xerographic reprint (U.S. prices).

POLITICAL SCIENCE THESAURUS. A major reference tool in political science; this volume represents the terminology control device for a computer-based information retrieval service. Individuals: Hardback, $\$ 20.00$; paper, \$15.00. Institutions: Hardback, $\$ 30.00$; paper, $\$ 25.00$.

APSA BIOGRAPHICAL DIRECTORY (Sixth Edition, 1973). Biographical information on over 7,000 Association members, plus names and addresses for approximately 12,500 members. Members: Hardback, $\$ 7.50$; paper, \$5.00. Non-Members: Hardback, $\$ 12.50$; paper, $\$ 10.00$.

APSA DIRECTORY OF MEMBERS: ANNUAL SUPPLEMENT TO THE APSA BIOGRAPHICAL DIRECTORY. Names and current addresses of all APSA members. $\$ 3.00$ each.

GUIDE TO PUBLICATION IN POLITICAL SCIENCE. Co-sponsored by the APSA Committee on the Status of Women and the Women's Caucus for Political Science. \$1.00.

ROSTER OF WOMEN IN POLITICAL SCIENCE (4th edition). Biographical information on women political scientists. $\$ 3.00$ each for members; $\$ 5.00$ for non-members.

ROSTER OF CHICANOS IN POLITICAL SCIENCE. Biographical information on Chicano political scientists. $\$ 3.00$ for members; $\$ 5.00$ for non-members.

ANNUAL APSA DIRECTORY OF DEPARTMENT CHAIRPERSONS. Names and addresses of Chairpersons of departments offering political science at four-year institutions. $\$ 20.00$ each.

ANNUAL APSA SURVEY OF DEPARTMENTS. Annual report on the results of an extensive questionnaire sent to all four-year institutions offering political science. Includes salary information, enrollment trends and many other items of current interest. $\$ 20.00$ each.

PERSONNEL SERVICE GUIDELINES FOR EMPLOYERS AND APPLICANTS. Pamphlet containing information and guidelines for members of the APSA Personnel Service and for employers listing their vacancies in the Personnel Service Newsletter. No charge.

PERSONNEL SERVICE NEWSLETTER. Monthly listing of positions for political scientists. APSA Members: $\$ 8.00$ subscription.

CAREERS AND THE STUDY OF POLITICAL SCIENCE: A GUIDE FOR UNDERGRADUATES. A monograph discussing the relationship between political science knowledge and skills and careers in law, government, business, journalism, teaching, etc. $\$ .50$ each; bulk rates available.

\footnotetext{
* Order from: Customer Service Department

University Microfilms

300 North Zeeb Road

Ann Arbor, Michigan 48106
} 
CAREER ALTERNATIVES FOR POLITICAL SCIENTISTS: A GUIDE FOR FACULTY AND GRADUATE STUDENTS, by Thomas E. Mann. A monograph containing practical advice for obtaining nonacademic employment. $\$ 1.00$ each.

GUIDE TO GRADUATE STUDY IN POLITICAL SCIENCE. Compilation of Ph.D. and Masters programs in political science. The 1977 Guide is revised and expanded to include listings of faculty and fields of specialization. $\$ 4.00$ each.

RESEARCH SUPPORT FOR POLITICAL SCIENTISTS. A monograph containing detailed listings of public and private agencies that fund research fellowships, grants, and contracts. Includes section on strategic thinking about funding research and a guide to preparing research proposals. $\$ 4.00$ each.

STORMING WASHINGTON: AN INTERN'S GUIDE TO NATIONAL. GOVERNMENT by Stephen Frantzich. A monograph on Washington, D.C. internships. $\$ 2.00$ each.

GLOBAL DIMENSIONS IN U.S. EDUCATION. A joint publication of the APSA Committee on Pre-Collegiate Education, the Education Commission of the International Studies Association, and the Center for War/Peace Studies of the N.Y. Friends Group, Inc. Four publications: The Elementary School, The Secondary School, The University, The Community. $\$ 1.50$ each, $\$ 5.00$ per set.

COMPARING POLITICAL EXPERIENCES. Complete description of an alternative course for high school government instruction. $\$ 2.75$ each.

SETUPS: AMERICAN POLITICS (Supplementary Empirical Teaching Units in Political Science). New computer related instructional materials whereby students learn important substantive topics in American politics as they learn methods of analysis. Voting Behavior: The 1972 Election by Bruce D. Bowen, C. Anthony Broh, Charles L. Prysby. Political Socialization Across the Generations by Paul Allen Beck, Jere W. Bruner, L. Douglas Dobson. Political Participation by F. Christopher Arterton, Harlan Hahn. Representation in the United States Congress: 1973 by Ray A. Geigle, Peter G. Hart jens. The Supreme Court in American Politics: Policy Through Law by John Paul Ryan, C. Neal Tate. U.S. Energy, Environment and Economic Problems: A Public Policy Simulation by Barry Hughes. The Dynamics of Political Budgeting: A Public Policy Simulation by Marvin K. Hoffman. For information and price list write: APSA Division of Educational Affairs. $\$ 3.50$ each; lower price on bulk orders.

INSTRUCTIONAL RESOURCE MONOGRAPHS. Guides on materials and methods for teaching and learning in political science. A Guide to Library Sources in Political Science: American Government by Clement E. Vose, $\$ 6.50$ hardback, \$4.00 paperback. PSI and Political Science: Using the Personalized System of Instruction to Teach American Politics, edited by Ralph B. Earle, Jr., $\$ 3.50$ paperback. Simple Simulations, by Charles Walcott with Anne Walcott, $\$ 3.50$ paperback. Computer-Assisted Instruction in Political Science, edited by Jonathan Pool, $\$ 4.00$ paperback. U.S. Census Data for Political and Social Research: A Resource Guide, \$4.00, and U.S. Census Data for Political and Social Research: A Student Manual, \$2.50, both by Phyllis G. Carter. The Case of the Unreturned Cafeteria Trays by Lloyd S. Etheredge, \$1.00 each.

LEGISLATIVE SERVICE PROJECT MANUALS. Individual manuals available for: California, Kansas, Kentucky, Montana, Ohio, Oregon, Rhode Isiand. $\$ 2.50$ each.

POLITICAL SCIENCE AND STATE AND LOCAL GOVERNMENT. A volume on the current and future state of research and educational programs in the field of state and local government. $\$ 3.75$ each.

APSA MEMBERSHIP MAILING LISTS AND LABELS. For information and price list, contact Membership Secretary, APSA.

APSA POLITICAL SCIENCE DEPARTMENT CHAIRPERSONS MAILING LABELS. For information and price list, contact APSA Departmental Services Program.

\section{Order Form}

I am enclosing a check for $\$$ , for the following publications:

Name

Address

City State Zip

All orders must be prepaid.

Order from: American Political Science Association

1527 New Hampshire Avenue, N.W.

Washington, D.C. 20036 


\section{FULL AND FAST REFERENCE \\ IN POLITICAL SCIENCE?}

TRULY INTERNATIONAL COVERAGE ?

IPSA TRIES HARD I

Do you have easy access to the hundreds of journals which publish articles in political science, public administration and international relations all over the world? At a time when many libraries must take a close look at their budgets, can you and your students dispense with the ever fuller and faster services provided by INTERNATIONAL POLITICAL SCIENCE ABSTRACTS?

A non-commercial journal published bimonthly by the International Political Science Association itself, the Abstracts provides summaries of articles in both specialized and non-specialized journals, including major yearbooks. Articles in English are abstracted in English; articles in other languages (approximately $30 \%$ ) are abstracted in French. From 1,450 abstracts in 1968 the progress has been to 5,040 abstracts in 1977. Each issue carries a detailed subject index and a list of the 600 periodicals examined; the final issue of each annual volume contains a cumulative subject index and an author index. Back volumes are again available (from vol. 1, 1951).

Your own Library should have a full set of the Abstracts. The institutional subscription for 1978 costs French Francs 400 (approximately $\$ 81.50, £$ st. 47$)$. Individuals may subscribe at a reduced rate of F.F. 125 (approximately $\$ 25$, £ st. 15). Specimen on request.

INTERNATIONAL POLITICAL SCIENCE ABSTRACTS 27, RUE SAINT-GUILLAUME, 75007 PARIS, FRANCE 


\section{KENTUCKY}

THE CONTEXT OF ENVIRONMENTAL POLITICS

Unfinished Business for America's Third Century

Harold \& Margaret Sprout

"A well-balanced, realistic assessment of the nation's ability to cope with its environmental problems . . . helps to meet a long-standing need for books that examine environmental politics in their full dimensions "-Lynton $K$. Caldwell 224 pages $\$ 9.75$

PRESIDENT EISENHOWER \& STRATEGY MANAGEMENT A Study in Defense Politics

Douglas Kinnard

"A lively, informative, and balanced account of Ike's style and policy content . . filled with insights."-Library Journal. "Scholars in this period will be forced to take into account Kinnard's original and unorthodox analysis."-Robert Gilpin 181 pages $\$ 13.75$

\section{THE MISSILE DEFENSE CONTROVERSY}

Strategy, Technology, and Politics, 1955-1972

Ernest J. Yanarella

"A wonderfully useful contribution to the critical study of technology and public life." - Langdon Winner

248 pages $\$ 17.25$

\section{THE POLITICS OF CITY-COUNTY MERGER}

The Lexington-Fayette County Experience

W. E. Lyons

A case study of the successful 1972 Lexington and Fayette County, Kentucky, merger.

"No reformer should venture into the complex thicket of consolidation 'politics' without having read The Politics of City-County Merger." - Vincent L. Marando 192 pages $\$ 13.50$

\section{THE WHEEL OF SERVITUDE}

Black Forced Labor after Slavery

Daniel A. Novak

Foreword by Bayard Rustin

"Fresh and rather surprising. The book does not tell a pretty story, but it is a necessary one, and sheds a great deal of light on a neglected chapter in our legal history." - Lawrence M. Friedman

144 pages $\$ 9.50$ 


\title{
For your second-semester courses...
}

\author{
Barbara Hinckley \\ New! STABILITY AND CHANGE IN CONGRESS \\ SECOND EDITION
}

With emphasis on recent research and developments, this brief text provides a thorough and integrated treatment of the major areas of congressional study. This edition features discussions of current congressional reforms, the renovation of staff and budgeting procedures, and the recent action on presidential impeachment. For the undergraduate, the book can be used as a basic text or a supplementary text in legislative behavior and Congress courses; for upper-and graduate-level courses, it is a concise source of up-to-date research on the subject. 224 pages, $\$ 6.95 /$ paper tentative. August 1978. ISBN 0-06-042839-2.

\section{Jack Levin \\ ELEMENTARY STATISTICS IN SOCIAL RESEARCH SECOND EDITION}

This text introduces statistics to students of sociology and related fields who have not had extensive truining in mathematics. Emphasis is on applica- tions rather than derivations. Solutions Manual 293 pages; \$13.95. 1977. ISBN 0-06-043985-8. Workbook: $\$ 5.50$.

\section{William J.Crotty \\ POLITICAL REFORM AND THE AMERICAN EXPERIMENT}

Presents the author's original thinking on voting, campaign financing, and the structure of presiden- tial nominating systems and political parties. 312 pages; $\$ 7.50$ /paper. 1977 . ISBN 0-690-00869-4.

\section{Michael Curtis \\ COMPARATIVE GOVERNMENT AND POLITICS SECOND EDITION}

This core volume in Harper's Comparative Government Series examines comparative politics analytically and functionally. Contemporary exam- ples are drawn from a wide range of regimes, institutions, and forms of political behavior. 288 pages; $\$ 6.95$ /paper. February 1978. ISBN 0-06-041462-6.

\section{John S. Reshetar, Jr. \\ THE SOVIET POLITY: \\ Government and Politics in the U.S.S.R. SECOND EDITION}

This comprehensive text makes sense of Soviet politics within the broader context of the Russian political tradition, relates communist doctrine to Soviet political practice, and evaluates the Soviet regime's problem-solving capabilities. 432 pages; $\$ 8.95$ / paper. May 1978. ISBN 0-06-045396-6.

To request examination copies, please write to Alec Lobrano,

Dept. 605 . Include course title, present text, and enrollment. Third Edition... Coming January'79
Prewitt \& Verba's AN INTRODUCTION TO AMERICAN GOVERNMENT... 


\section{New from California}

\section{Pride and Solace}

The Functions and Limits of Political Theory

\section{Norman Jacobson}

Jacobson presents a novel perspective of the history of political theory. He wages an intellectual struggle on two fronts: against the prideful offer of salvation by political means, and the stoical rejection of solace in any form whatever.

181 pages, $\$ 10.00$

\section{The Writs of Assitance Case}

\section{H. Smith}

In this first book-length treatment of the Writs of Assistance case Smith has broken much new ground: he uncovers the juridical origins of the writ, and elucidates the basics of customs law. The core of the book is the courtroom arguments themselves and the development of the case.

601 pages, $\$ 30.00$

\section{Kings or People}

Power and the Mandate

to Rule

\section{Reinhard Bendix}

"Kings or People is equal to the grandeur of its subject: the political origins of the modern world. ... One of the truly powerful ventures in comparative historical sociology to have appeared in recent years." - Clifford Geertz

704 pages, 75 halftones, 12 maps, $\$ 20.00$

\section{Revised Edition- King John \\ W. L. Warren}

"Takes its place as the standard biography." -New York Times Book Review

"The sort of biography which is enjoyable reading in itself. But 'King John' is more: it is good history." - Christian Science Monitor 352 pages, 8 halftones, cloth $\$ 15.00$, paper $\$ 4.95$

\section{Women in Soviet Society}

Equality, Development, and Social Change

\section{Gail Warshofsky Lapidus}

An interdisciplinary approach to the analysis of the official Soviet commitment to female liberation and its implications for the role of women in Soviet Society today.

"Unquestionably the best available study in the field." - Alexander Dallin

391 pages, $\$ 17.50$

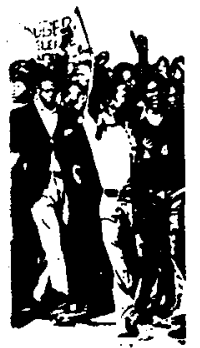

\section{Black Power in South Africa}

The Evolution of an Ideology

\section{Gail M. Gerhart}

The suppression of black aspirations over many generations has yielded today a renewed mood of defiant nationalism among South Africa's black majority. Documentary research and extensive interviews with nationalist leaders have enabled Gerhart to chart the development of this mood over the past three decades.

Perspectives on Southern Africa \# 19

350 pages, $\$ 14.50$

\section{Marcus Foster and the Oakland Public Schools}

Leadership in an Urban Bureaucracy

\section{Jesse J. McCorry}

Marcus Foster, Superintendent of Oakland Public Schools from April 1970 to his death in November 1973, introduced a program of reforms in response to charges of rigidity, insensitivity to community needs, and inefficiency in the city's school bureaucracy. McCorry reviews the relative success of these reforms.

178 pages, $\$ 10.95$

\section{Scandal and Reform \\ Controlling Police Corruption}

\section{Lawrence $W$. Sherman}

Little is known about the conditions under which scandals occur or what effects scandal has on organizations. The common wisdom that scandal leaves an organization demoralized and ineffective is not supported by this study of four police departments, three of which were reformed in the wake of scandal. 304 pages, $\$ 14.50$ 

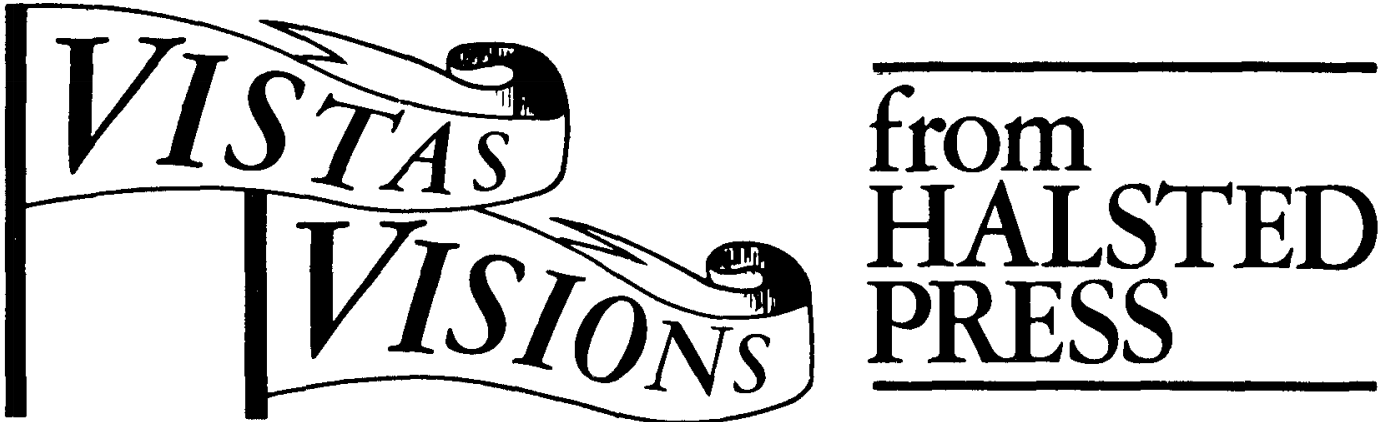

\section{THE NATURE OF \\ INTERNATIONAL SOCIETY}

C.A.W. Manning

This unusual book's importance lies in its novel, informal handling of such topics as the quality of communal thought and feeling, international applications of ethics, the state's ontological status, elements of make-believe in social arrangements, the role of myth in political belief, and the explanation of legal commitment. (Rights: U.S. \& Canada)

$\begin{array}{llll}(047056760-0) & 1976 & 220 \text { pp. } & \$ 19.75\end{array}$

\section{THEORIES OF REVOLUTION}

\section{A. S. Cohan, University of Lancaster}

Compares and analyzes various political, sociological, and psychological theories of revolution. In his examination of such theorists as Marx, Johnson, Smelser, Arendt, Rummel, and Dahrendorf, the author suggests a broader concept of revolution to include factors other than violent political change: (Rights: U.S.)
(0470 26346-6)
1978
$228 \mathrm{pp}$.
$\$ 7.95$ paper

\section{THE DISINHERITED CHILDREN}

\section{A Study of the New Left}

\section{and the Generation Gap}

Christopher Bone, Washington State Universit!'

Examines the development and philosophical foundations of the New Left and counterculture, discussing their historical significance in terms of Western civilization. (A Schenkman publication)
(0 $47008771-4)$
$1977184 \mathrm{pp}$
$\$ 5.95$ paper

\section{THE CIRCUMPOLAR NORTH}

A Political and Economic Geography of the Arctic and Sub-Arctic

Terence Armstrong, University of Cambridge.

George Rogers \& Graham Rowley

A study of contemporary northern lands and seas in transition which is also a case study in regional development.

(Rights: U.S.)

(0470 26403-9) 1978

approx. 350 pp. $\$ 30.00$ (tent.) cloth

(0470 26411-X) \$14.95 (tent.) paper

\section{CRITICAL SOCIOLOGY}

Edited by J. W. Freiberg, Boston Iniversity

Europe's leading social theorists discuss a wide variety of contemporary issues. Includes papers on many different kinds of Marxism, all written from humanistic, libertarian points of view. (An Irvington publication)

(0 470 26425-X) 1978

approx. 400 pp. $\$ 16.50$ (tent.)

\section{CRISIS MANAGEMENT}

Conflict, Confrontation, and Diplomacy

Philip Williams, University of Aberdeen

A study of crisis management as developed in the academic literature and practiced by the United States, the Soviet Union, and the People's Republic of China. (Rights: U.S.)

$(047098899-1) \quad 1976 \quad 230$ pp. $\$ 16.95$

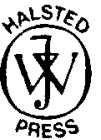

HALSTED PRESS

a division of John Wilev \& Sons, Inc

605 Third Ave.

New York, N.Y. 10016

Mail to: Dept. 313 APSR 70

HAISTED PRESS, a division of John Wiley \& Sons, Inc 605 Third Ave

New York, N.Y. 10016

Please send me the books indicated below for 30 days free examination.

\footnotetext{
$\square$ Manning (0 470 56760-0)

$\square$ Cohan (0 470 26346-6)

$\square$ Bone (0 470 08771-4)

$\square$ Armstrong (0 470 26403-9)

$\square$ Armstrong (0 $47026411-X)$

$\square$ Freiberg $(047026425-X)$

$\square$ Williams (0 470 98899-1)

$\square$ BILL ME + postage/handling. If your order totals $\$ 75$ or more, attach a purchase order or enclose $25 \%$ partial payment.

PAYMENT ENCLOSED + applicable sales tax. Halsted pays postage/handling. We usually ship within 10 days. If paymen accompanies order and shipment cannot be made within 90 days, full payment will be refunded. Foreign payment must be made in U.S. currency, by U.S. bank draft, international money order, or UNESCO coupons.

Please print.

NAME

AFFILIATION

ADDRESS

CITY STATE ZIP

Prices subject to change without notice and stightly higher in Canada. IN CANADA: John Wiley \& Sons Canada, Ltd., 22 Worcester Road, Rexdale, Ontario. 


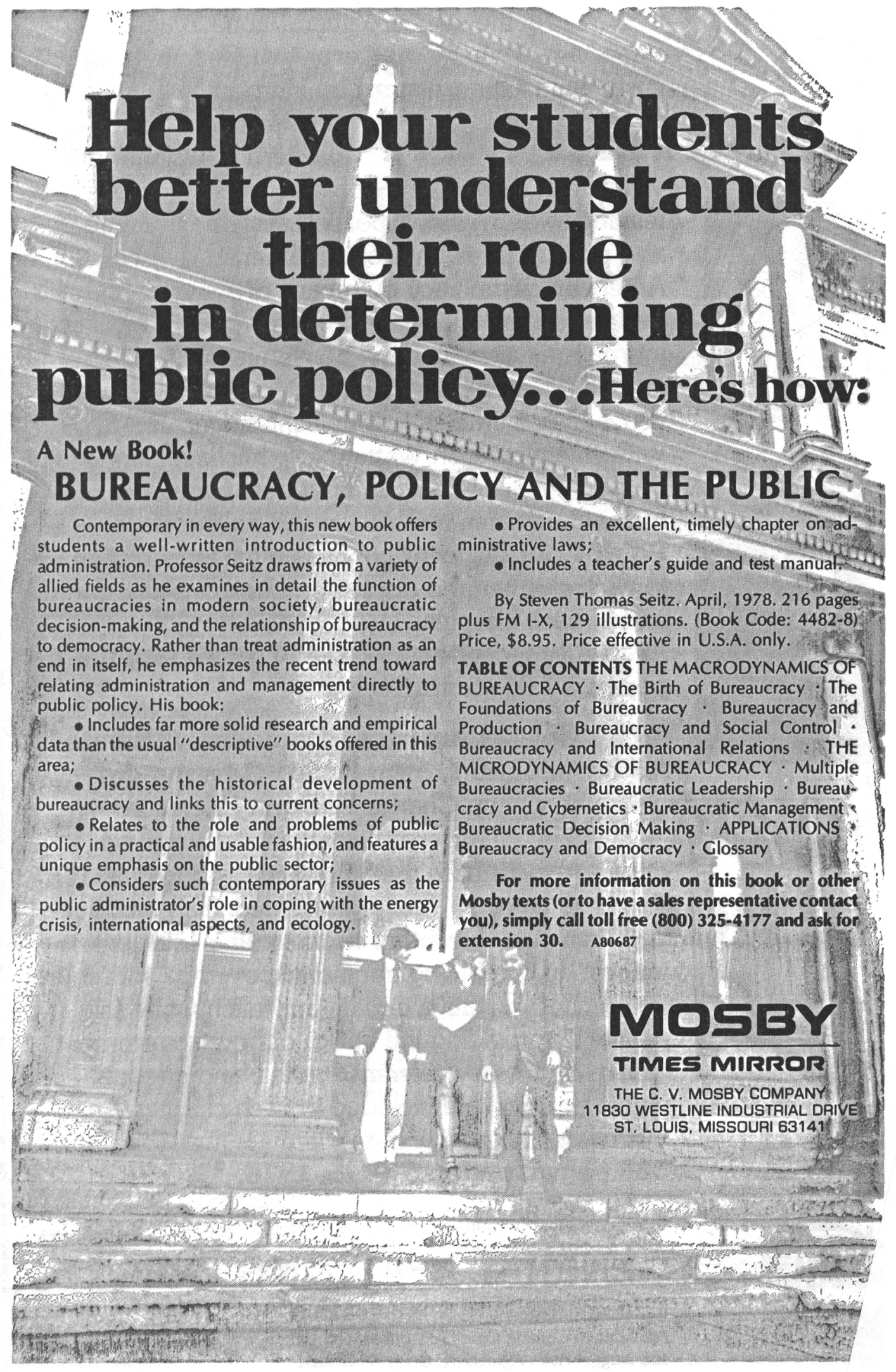




\section{POINT-}

Avoiding the standard liberal/conservative response, Point-Counterpoint: Readings in American Government by Herbert M. Levine COUNTERPOINT (Univesity of Southwestern Louisiana) provides fresh insights and constructive suggestions

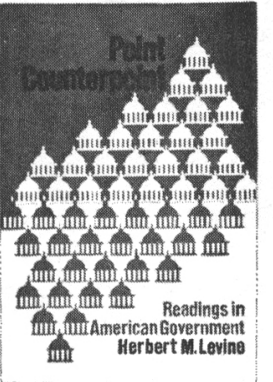
relating to our nation's political system, structure, and policies. It examines fundamental questions of American democracy by means of a stimulating debate format. Authors from the worlds of politics, journalism, literature, and academia include among others who present their views on the vital issues of our time - Arthur Schlesinger, Jr., William Colby, Ben Wattenberg, Michael Har-

\section{and}

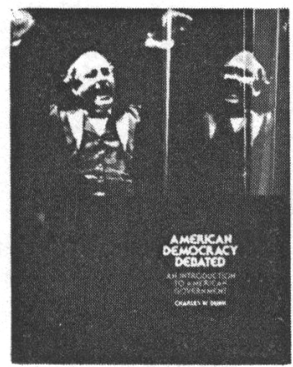
rington, Henry Kissinger, Theodore Sorenson, Barry Goldwater, and Alexander Solzhenitsyn. Point-Counterpoint contains a full introduction to each chapter and discussion questions at the end of each chapter.

Available October, 1978, 450 pages (approx.), paper, $\$ 7.95$ (tentative)

Each chapter of American Democracy Debated: An Introduction to American Government

\section{ATERT ANT by Charles W. Dunn (Clemson} University) is organized around a debate - with both the affirmative and negative

DER 10 Sides presented. This introductory text stimulates student interest by combining traditional coverage with the

DE ATP innovative debate approach while still providing the basics of how government works. A glossary, reference notes, and a rebuttal reading section are included in each chapter. An

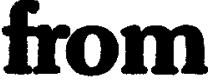
Instructor's Manual with test items is available. 560 pages, paper, \$10.95, 1978.

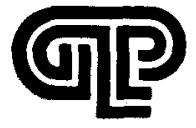

To request examination copies, please write Manager, College Sales

\section{GENERAL LEARNING PRESS}

Morristown, New Jersey 07960, Box PSR978

Available in Canada from GLC Publishers, Ltd.,

155 Nugget Ave., Agincourt, Ontario M1S3B1 


\section{Provides the political, economic, and social background needed to understand world events as they occur . . . and to look ahead to their consequences}

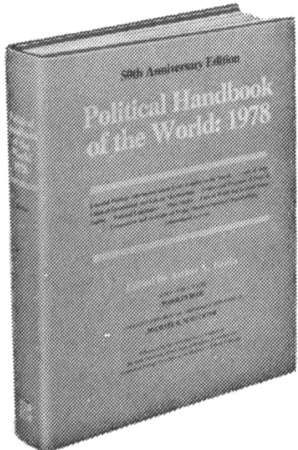

POLITICAL HANDBOOK OF THE WORLD: 1978

Edited by Arthur S. Banks. Sponsored by the Council on Foreign Relations. Prepared by the Center for Social Analysis of the State University of New York at Binghamton. Associate Editor, Marilyn Bier. Intergovernmental Organization Editor, Michael G. Schecter.
This remarkable storehouse of vital political, economic, and social data covers every independent nation on earth. It represents a massive task of research and scholarship, bringing together a vast range and quantity of information for each nation.

\section{A compendium of vital knowledge- presented country by country}

You'll find thorough, reliable coverage of political issues, social and economic data, legislatures, foreign relations, names of heads of state, cabinet members, official languages, news media, imports and exports, religions, geography, climate, and much more.

\section{Authoritative, in-depth coverage of major} intergovernmental organizations

There are complete details on the membership, structure, and activities of all major intergovernmental organizations, including: UN and UNrelated bodies ... regional, economic, developmental, security, and commodity organizations ... river commissions . . . and many others.

An invaluable survey of today's international and regional issues

For the first time in this edition, there is an im- mensely useful overview of the events and issues that are of major international significance, accompanied by discussions of current regional issues in Western Europe, Eastern Europe, Latin America, East Asia, South Asia, Southeast Asia, and Sub-Saharan Africa.

Now in its 50th Anniversary Edition, the Handbook is the most comprehensive, authoriative, and easy-to-read single-volume reference to political events available anywhere.

Just off the presses, the 1978 edition of this unique annual reference provides instant access to ...

- Essential political information about every country in the world

- Names of heads of state, chiefs of government, and cabinet membership

- Names of leaders and programs of the major political parties

- Composition of national legislatures

- Mass media

- Current world and regional issues

- Composition and activities of major intergovernmental organizations

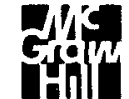

\section{McGraw-Hill Book Company}

1221 Avenue of the Americas

New York, N.Y. 10020

Please send POLITICAL HANDBOOK OF THE WORLD $1978(003690-x)$ for 15 days' free examination. If decide to keep it, I will remit -check one-

$1 \$ 24.95$ plus tax, postage, and handling.

$\square$ \$12.95 plus tax, postage, and handling in 15 days and $\$ 12.00$ one month later.

If I decide after 15 days that I do nol want the book, I will return il without lurther obligation.

Extra savings opportunity.

I am remitting cash for the full amount of the book, plus tax, and McGraw-Hill will pay all regular postage and handling costs. Same 15-day free examination and return privileges apply. This onder subject to acceptance by McGrow-Hill

\section{SPECIAL SUBSCRIPTION PRICE OFFER}

By ordering the POLITICAL HANOBOOK OF THE WORLO: 1978 now and at the same time subscribing to updated, revised future annual editions, I will receive this volume at the special subscriber's price of $\$ 17.50$ plus loca tax, postane, and handling $\rightarrow$ 30\% saving. Free 15 days' examination and relurn privileges still apply. Even if future price increases are necessary my subscription will insure that I receive at least a $30 \%$ discount on the lis price.

$\square$ Check here to take advantage of this special subscription offer.

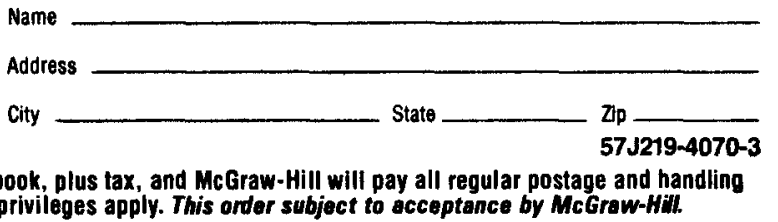




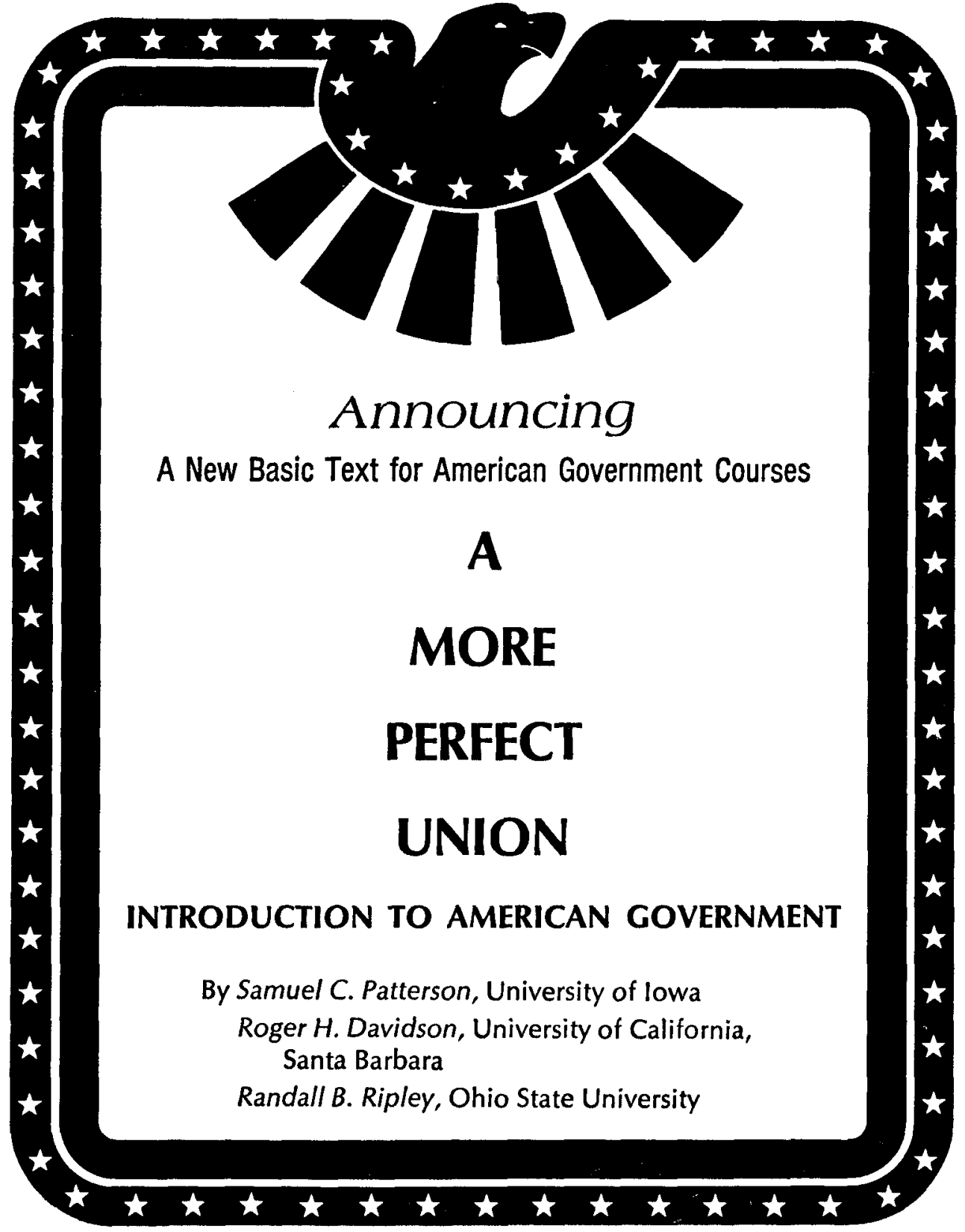

To Be Published in January, 1979 THE DORSEY PRESS

Homewood, Ill. 60430 


\section{UTOPIA AND REVOLUTION Melvin J. Lasky}

"A remarkable achievement, covering nearly five centuries of Western ideas, symbols, and metaphors - all brought, sometimes dazzlingly, within the revolutionary fold." - New York Times Book Review

Paper xiv, 726 pages $\$ 10.95$ September

\section{THE CONSTITUTION}

\section{OF LIBERTY}

\section{F. A. Hayek}

"One of the great political works of our time, ... the twentieth-century successor to John Stuart Mill's essay, 'On Liberty.' - Henry Hazlitt, Newsweek

Paper $\mathbf{5 7 6}$ pages $\$ 7.95$ September

\section{SOCIOLOGISTS, ECONOMISTS AND DEMOCRACY}

With a new Preface

Brian Barry

Barry evaluates both the "economic" and the "sociological" approach to political theory in this updated study of democratic politics.

Paper viii, 202 pages $\$ 3.95$ September

\section{LAW, LEGISLATION AND LUBERTY}

Volume II

The Mirage of Social Justice

\section{F. A. Hayek}

"An intriguing and articulate reformulation of classical liberalism in the light of contemporary politics." - Thomas J. Quinn, Journal of Legislation

\section{THOUGHTS ON MACHIAVELLI Paper xiv, 196 pages $\$ 4.95$ Available Leo Strauss}

Strauss asserts that Machiavelli's teaching is "immoral and irreligious" even though it possesses "a perverted nobility of the highest order."

Paper 352 pages $\$ 5.95$ September

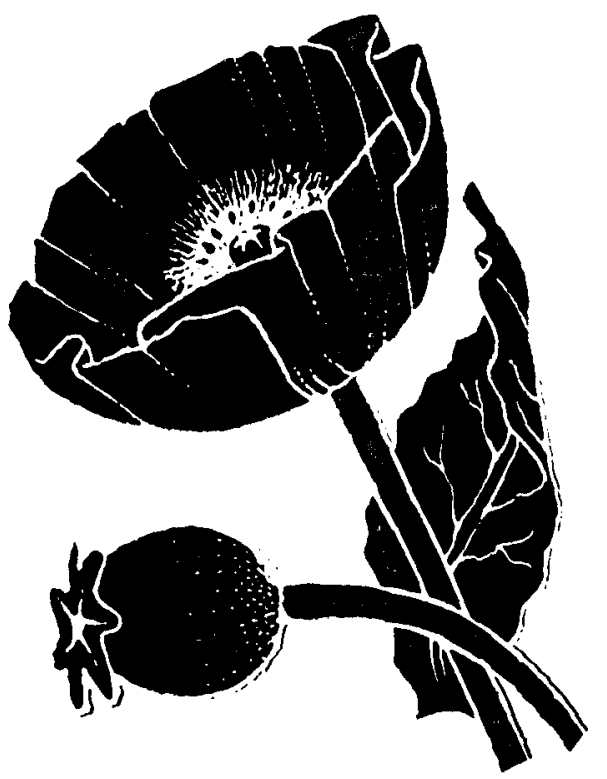

\section{THE GENTLEMEN'S CLUB}

International Control of Drugs and A/cohol Kettil Bruun, Lynn Pan and Ingemar Rexed

Foreword by Norval Morris

"[This work] is the finest study ever made of a United Nations activity or of international drug control." - Richard H. Blum, Stanford University

Paper xiv, 338 pages $\$ 5.95$ Available

THE UNIVERSITY OF CHICAGO PRESS

\section{Chicago 60637}




\section{WINNER of APSA's Gladys M. Kammerer Award}

Best Book in 1977 on United States National Policy

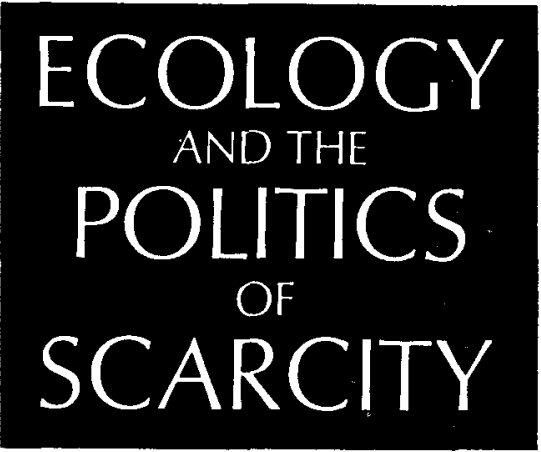

\section{William Ophuls}

"Should be required reading for every politician, philosopher, businessman, and church member. ... Ophuls deals with the changes in basic institutions that scarce energy and food will make necessary."-Choice

"An excellent and brave book which dares to fill a heretofore lamentable gap between scientific discussions of environmental problems ... and the social and political implications of those problems. ... I definitely plan to use the book as a required text in my course on Environment, Technocracy and the Citizen."-L. Rupert Chambers, The University of Texas, Austin

"Easily the best philosophical treatment of our ecological dilemmas to date. .. . Ophuls brings a great wealth of analysis to a very timely and difficult area of human concern."-A. Daniel, University of Hawaii

"This is an excellent text on the political theoretical ramifications of the current and future ecological crisis. I will use this book as the central text for undergraduate Environment Politics and will expose the book to graduate students for their evaluation."-Jon Gzarnecki, SUNY, Buffalo

\section{W. H. FREEMAN AND COMPANY}

660 Market Street, San Francisco, CA 94104

I am considering Ophuls's Ecology and the Politics of Scarcity for class adoption. $\times 9817$
Write for a complimentary copy on your department letterhead or mail this coupon.
Name - Title
School - Enrollment
Course
Address - State 


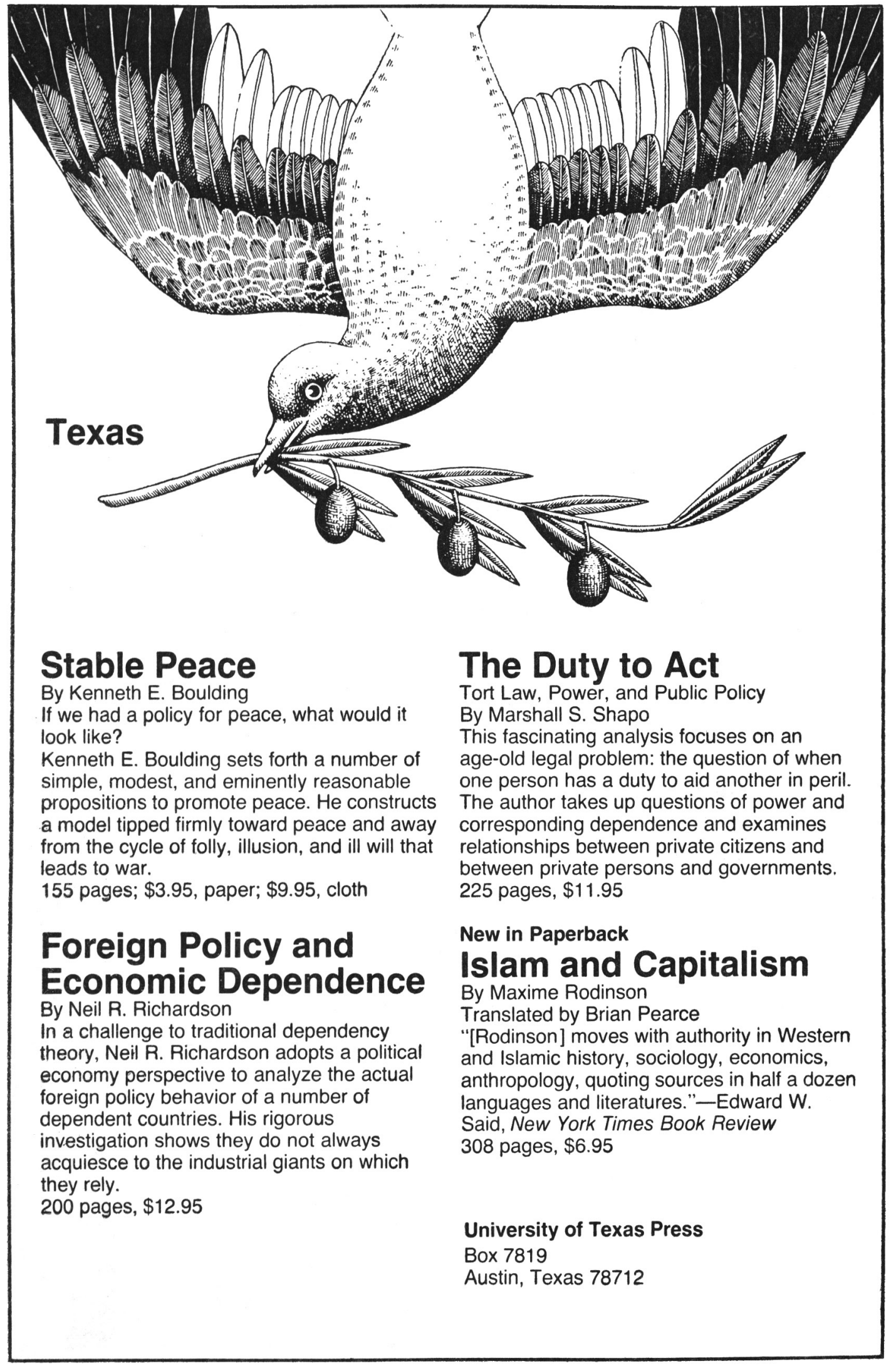




\section{ISLAND CHINA}

\section{A Twentieth Century Fund Study}

\section{Ralph N. Clough}

"Ralph Clough links practice and theory in the best tradition of diplomatic specialists on Asia who have become noted scholars. Here he gives us a balanced, sober, comprehensive and thoughtful analysis of a problem that is increasingly drawing the attention of the Carter Administration." -Jerome A. Cohen, Harvard Law School

$\$ 12.50$

\section{THE SPIRIT OF LIBERALISM}

Harvey C. Mansfield,Jr.

Attempting to restore resilience to liberalism, Mansfield's essays go back to the sources of liberal thought. He criticizes several recent spokespeople for modern liberalism in a book that will encourage many to reexamine their political consciences.

$\$ 13.50$

\section{THE VILLAGE ENTREPRENEUR}

\section{Change Agents in India's}

Rural Development

Wayne G. Broehl,Jr.

Broehl and his associates interviewed hundreds of rural business people to pinpoint the qualities that distinguish change agents from their tradition-bound comrades. The book describes a pilot program established to engender innovative attitudes, and provides a model that will help apply this new development strategy to other fields and countries.

$\$ 18.50$

\section{Harvard University Press} Cambridge, MA 02138

\section{CUBA}

\section{Order and Revolution}

Jorge I. Domínguez

This book is the first major historical analysis of 20th-century Cuba. It will be invaluable to anyone seeking to understand the Cuban government and people.

"Cuba: Order and Revolution will be the definitive study on twentieth century Cuba. . . It will become a landmark study." -Edward Gonzalez Belknap $\$ 25.00$

\section{NOW IN PAPER}

\section{THE JAPANESE}

\section{Edwin O. Reischauer}

"A masterly explanation of who the Japanese are, how they got that way, and what they might become in the future. . . The book reads beautifully, like a long, quiet and informal chat in your favorite professor's study."-New York Times Book Review

Belknap $\$ 15.00$ cloth; $\$ 5.95$ paper

\section{TAKING RIGHTS SERIOUSLY}

\section{Ronald Dworkin}

"Ronald Dworkin's Taking Rights Seriously is the most important work in jurisprudence since H.L.A. Hart's The Concept of Law. . . This is a book that should be read by anyone who cares about our public life-either in theory or in practice."-Marshall Cohen, New York Review of Books

$\$ 12.00$ cloth; $\$ 4.95$ paper

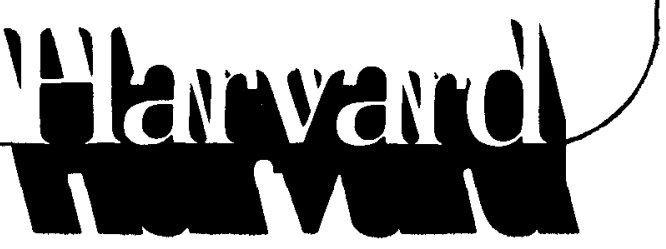




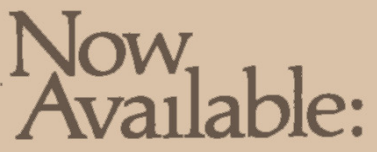

\section{John Randolph of Roanoke By Russell Kirk}

A masterful study of one of America's best, but leastknown, political thinkers. Included in this third edition are appendices containing several of Randolph's most important speeches and a representative selection of his letters. Dr. Kirk is author of The Conservative Mind and other books. "Never has an historian of politics done a better job of this kind"-Samuel Flagg Bemis in The Yale Review. "Kirk's scholarship is admirable"-New York Herald Tribune. "An able championship of conservative philosophy"-American Historical Review. "Will move its reader pleasantly through a chapter of American history that too commonly is told only from the dominant, the Jeffersonian, side of the record"-St. Louis PostDispatch. Hardcover \$9.00, Paperback \$3.50.

\section{Arator}

\section{By John Taylor}

The most popular and influential work by John Taylor of Caroline, foremost philosopher of the conservative Jeffersonians. This edition includes sixty-four essays, practical and political, on farming and the social order of an agricultural republic. Edited and with an introduction by M. E. Bradford. Hardcover $\$ 9.00$, Softcover $\$ 3.00$.

\section{LibertyPress LibertyClassics}

We pay postage on prepaid orders.

To order these books, or for a copy of our catalog, write:

LibertyPress/LibertyClassics

7440 North Shadeland; Dept. 186

Indianapolis, Indiana 46250 


\section{TIAA-CREF}

\section{Supplemental}

Retirement

Annuities

\section{for tax-deferred annuity programs}

Supplemental Retirement Annuities (SRA's) are new forms of TIAA and CREF contracts designed expressly for use by persons who want to set aside tax-deferred retirement funds over and above amounts being accumulated under their institution's basic retirement plan. They are available for employees of colleges, universities, private schools and certain other nonprofit educational organizations with tax-deferred annuity (salary-or-annuity option) programs. Through a properly drawn agreement with their institution, staff members may divert part of their compensation before taxes to the purchase of these new contracts.

\section{And SRA's are cashable at any time. This means that}

if the money accumulated by salary reduction is needed before retirement, the SRA contracts can be surrendered for their cash value. Benefits, whether payable in cash or as income, are taxable as ordinary income when received.

For more information and answers to questions send for your copy of the booklet on Supplemental Retirement Annuities.

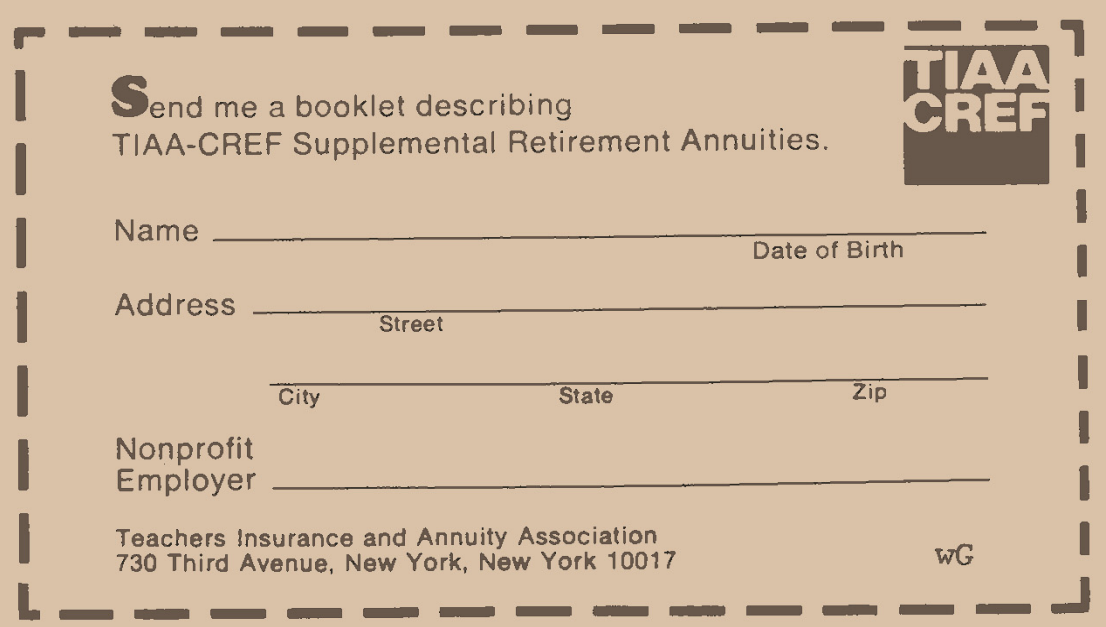

